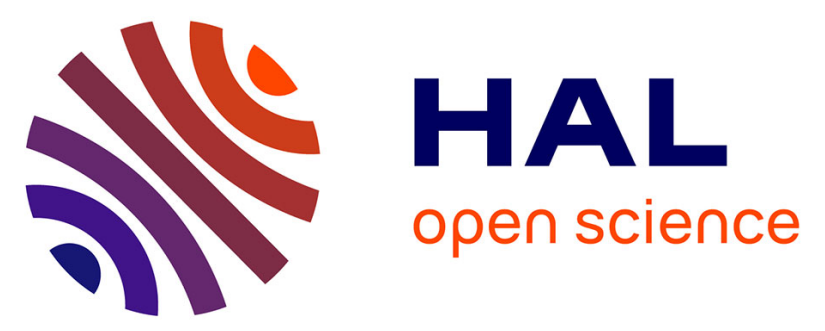

\title{
Cadomian volcanosedimentary complexes across the Ediacaran-Cambrian transition of the Eastern Pyrenees, southwestern Europe
}

Maxime Padel, J. Javier Alvaro, Josep Maria Casas, Sébastien Clausen, Marc Poujol, Teresa Sánchez-García

\section{To cite this version:}

Maxime Padel, J. Javier Alvaro, Josep Maria Casas, Sébastien Clausen, Marc Poujol, et al.. Cadomian volcanosedimentary complexes across the Ediacaran-Cambrian transition of the Eastern Pyrenees, southwestern Europe. International Journal of Earth Sciences, 2018, 107 (5), pp.1579-1601. 10.1007/s00531-017-1559-5 . insu-01644354

\section{HAL Id: insu-01644354 \\ https://hal-insu.archives-ouvertes.fr/insu-01644354}

Submitted on 6 Jul 2018

HAL is a multi-disciplinary open access archive for the deposit and dissemination of scientific research documents, whether they are published or not. The documents may come from teaching and research institutions in France or abroad, or from public or private research centers.
L'archive ouverte pluridisciplinaire HAL, est destinée au dépôt et à la diffusion de documents scientifiques de niveau recherche, publiés ou non, émanant des établissements d'enseignement et de recherche français ou étrangers, des laboratoires publics ou privés. 


\title{
Cadomian volcanosedimentary complexes across the Ediacaran-Cambrian transition of the Eastern Pyrenees, southwestern Europe
}

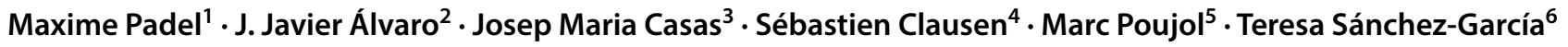

Received: 3 April 2017 / Accepted: 29 October 2017 / Published online: 21 November 2017

○) Springer-Verlag GmbH Germany, part of Springer Nature 2017

\begin{abstract}
The volcanism hosted by the Ediacaran-Terreneuvian Canaveilles Group of the Eastern Pyrenees displays two distinct geochemical affinities: (1) metabasites of the Nyer and Olette formations reflect the emplacement of a tholeiitic magmatism linked to extensional conditions, whereas (2) subsequent felsic and calc-alkaline magmatic rocks marking the top of the Olette Formation and forming the overlying Fabert and Finestrelles members represent Cadomian magmatic events. Based on U-Pb zircon dating constraints, palaeotopographic relationships linked to onlap geometries and distance from vent sources, three volcanosedimentary edifices can be distinguished, the so-called Tregurà (ca. 565-552 Ma), Cap de Creus (ca. 558 Ma) and Coll d'Ares (ca. 542-532 Ma) edifices. The top of their palaeoreliefs recorded locally the nucleation of centres of microbial carbonate productivity (Puig Sec Member) linked to synsedimentary tilting and karstification. Throughout West Gondwana, the presence of carbonate production across the Ediacaran-Cambrian transition is exclusively located in back-arc settings (Central-Iberian Zone) and areas far from the Cadomian subduction trench and devoid of significant terrigenous input, such as those reported in the Eastern Pyrenees and the neighbouring Montagne Noire.
\end{abstract}

Keywords Stratigraphy $\cdot$ Carbonate production $\cdot$ Volcanism $\cdot$ Geochemistry $\cdot$ LA-ICP-MS U-Pb dating · West Gondwana

\section{Introduction}

In West Gondwana, the Ediacaran-Cambrian transition is characterised by the onset and aftermath of the Pan-African and Cadomian orogenies (Ballèvre et al. 2001; Kroner and

Electronic supplementary material The online version of this article (https://doi.org/10.1007/s00531-017-1559-5) contains supplementary material, which is available to authorized users.

J. Javier Álvaro

jj.alvaro@csic.es

Maxime Padel

m.padel@brgm.fr

Josep Maria Casas

casas@ub.edu

Sébastien Clausen

sebastien.clausen@univ-lille1.fr

Marc Poujol

marc.poujol@univ-rennes1.fr

Teresa Sánchez-García

t.sanchez@igme.es
Stern 2004; Murphy et al. 2004), recording an arc-to-rift transition (Linnemann et al. 2007, 2008, 2014; Álvaro et al. 2014a; Pouclet et al. 2017) by the way of strike-slip and transform faults (Murphy et al. 1999; Nance et al. 2002; Keppie et al. 2003). Cadomian orogenic events are differently recorded in the southwestern (Iberian Massif) and northeastern (North-, Central and South-Armorican Domains, Massif Central and Pyrenees) branches of the Variscan Ibero-Armorican Arc. A distinct angular discordance is

1 BRGM, 3 Avenue Claude Guillemin, 45100 Orléans, France

2 Instituto de Geociencias (CSIC-UCM), Dr. Severo Ochoa 7, 28040 Madrid, Spain

3 Departament de Dinàmica de la Terra i de l'Oceà-Institut de recerca Geomodels, Universitat de Barcelona, Martí i Franquès s/n, 08028 Barcelona, Spain

4 UMR 8198 EEP CNRS, Université de Lille 1, Avenue Paul Langevin, 59655 Villeneuve d'Ascq, France

5 Géosciences Rennes, UMR 6118, OSUR, Université de Rennes 1, Campus de Beaulieu, 35042 Rennes, France

6 IGME, Ríos Rosas 23, 28003 Madrid, Spain 
recorded in the Iberian Massif (except in the Central-Iberian Zone, interpreted as a back-arc setting; Bandrés et al. 2002; Pereira et al. 2011) and in the North- and Central Armorican Domains, whereas the Ediacaran-Cambrian transition is conformable in the inner margin of the eastern branch (Occitan Domain of the southern Massif Central; Álvaro et al. 2014a, b; Pouclet et al. 2017).

As neither Cadomian deformation nor metamorphism has been documented in the Pyrenees, the Ediacaran magmatic rocks are the single distinct evidence for Cadomian events far from the Cadomian suture. Despite the recent publication of numerous $\mathrm{U}-\mathrm{Pb}$ zircon ages (e.g. Cocherie et al. 2005; Castiñeiras et al. 2008; Casas et al. 2015; Laumonier et al. 2015a, b, c), the age of some Cadomian-related volcanosedimentary complexes included in the Canaveilles Group remains contentious. In addition, many of their correlations are still exclusively based on lithostratigraphic comparisons. The record of Cadomian orogenic pulsations far from subduction sutures (such as those preserved in the Anti-Atlas, Ossa-Morena Zone and Armorican Massif) is still incompletely understood. In the Eastern Pyrenees, these volcanogenic levels were considered as reliable markers for correlations along short distances, but they are subject to drastic facies changes and intertonguing relationships.

A stratigraphic framework of felsic volcanosedimentary complexes associated with subsidiary basic lava flows and centres of carbonate production has been recently proposed by Laumonier et al. (2004, 2015a, b, c) and Álvaro et al. (in press) for the Ediacaran-Cambrian transition of the Eastern Pyrenees. Unfortunately, zircon U-Pb dating of these rocks yielded some confusion in what was considered a handful of correlatable stratigraphic marker beds encompassing a geochronological interval of ca. 32 my (580-548 Ma; Cocherie et al. 2005; Castiñeiras et al. 2008; Casas et al. 2015; Laumonier et al. 2015a, b, c). Therefore, a reassessment of available radiometric ages, completed with new $\mathrm{U}-\mathrm{Pb}$ dating of zircon obtained by LA-ICP-MS, appears to be necessary for better understanding the volcanogenic record preserved in the Eastern Pyrenees across the Ediacaran-Cambrian transition. The aim of this paper is to examine the stratigraphy, sedimentology and geochemistry of the volcanosedimentary complexes belonging to the uppermost part of the Canaveilles Group in the Eastern Pyrenees. In addition, we provide new $\mathrm{U}-\mathrm{Pb}$ zircon dating for some of the key volcaniclastic levels that have been arranged in a new updated stratigraphic framework of the Canaveilles Group.

\section{Geological setting and stratigraphy}

The Ediacaran-Cambrian volcanosedimentary record of the Pyrenees mainly crops out in the eastern part of the range, from the Mediterranean Sea to the Noguera-Pallaresa valley (Fig. 1). The dominance of unfossiliferous fine-grained siliciclastic sediments interrupted by marbles and scattered igneous rocks has rendered correlation and dating difficult

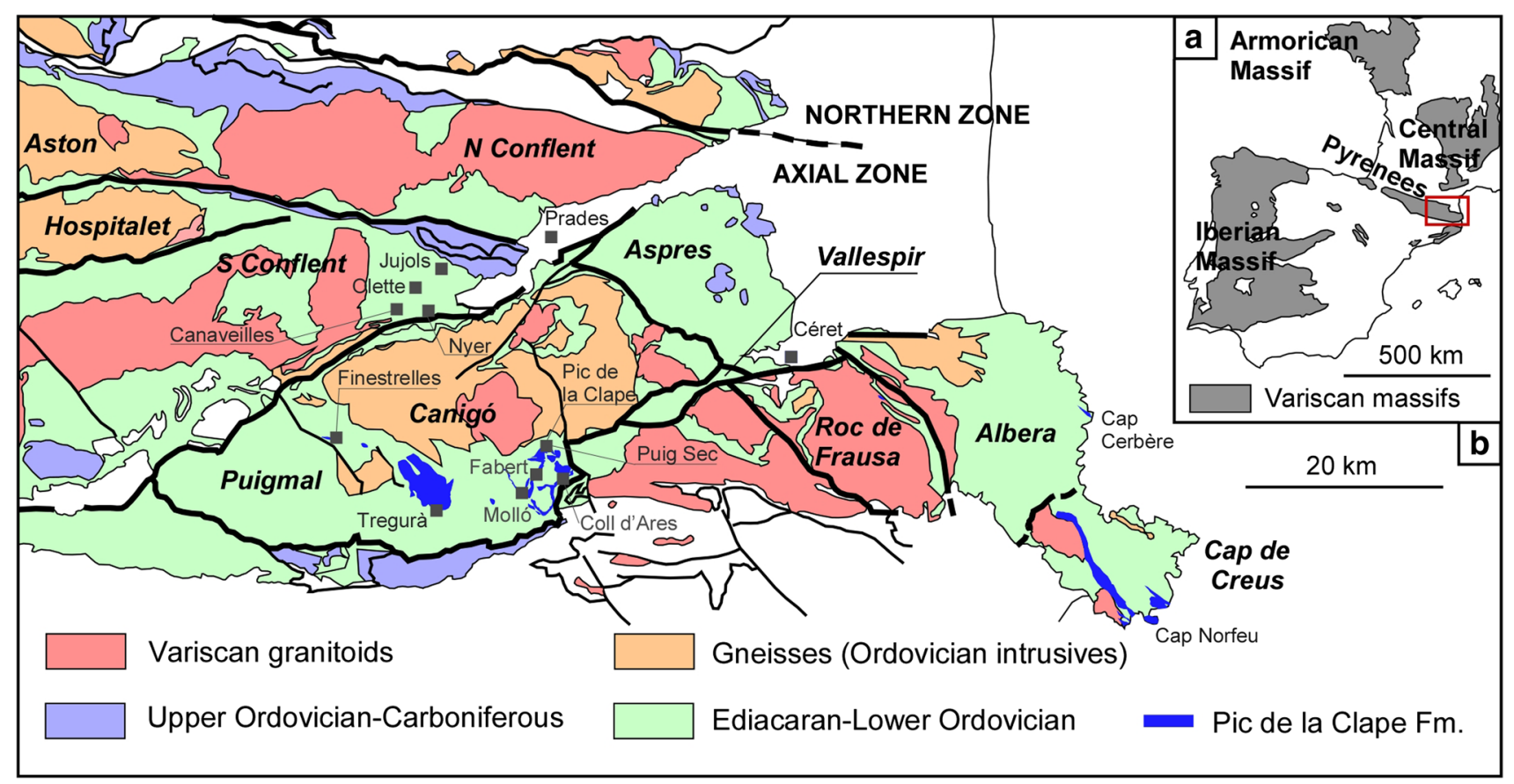

Fig. 1 Geological sketch of the Eastern Pyrenees. a Simplified geological map of the Eastern Pyrenees with location of Pre-Variscan exposures. b Geological map of the study area; modified from Baudin et al. (2008), Laumonier et al. (2015a, b) and Casas et al. (2015) 
(Guitard et al. 1998; Deloule et al. 2002; Laumonier et al. 2004; Cocherie et al. 2005; Castiñeiras et al. 2008).

The implications of the observed lithostratigraphic variation on the geodynamic evolution of the Ediacaran-Cambrian transition in the Eastern Pyrenees have been recently reevaluated by geological mapping (Baudin et al. 2008; Donzeau et al. 2010; Laumonier et al. 2015a, b, c) and the beginning of the "Référentiel Géologique de France" Program led by the French Geological Survey (BRGM). These studies have revealed the existence of several feldspar-rich tuffs and tuffites (or "micro-granulés") as well as volcanosedimentary bodies (referred in the geological maps as VS1VS2 marker levels and the Tregurà Formation, respectively) recognised in the Canigó/Canigou, Roc de Frausa/France and Albera/Albères-Cap de Creus tectonostratigraphic units (Fig. 1b).

In the Canigo unit, the traditional subdivision of the Ediacaran-Cambrian succession into the Canaveilles and Jujols “series" or groups (Cavet 1957; Laumonier et al. 1996, 2004) reflects an inherited stratigraphic framework that relied on the supposed intrusion of Cadomian granitic plutons surrounded by gneissic aureoles. These granitic plutons were recently dated as Ordovician, among others, by Cocherie et al. (2005), Castiñeiras et al. (2008), Denele et al. (2009), Casas et al. (2010), Liesa et al. (2011), Martínez et al. (2011) and Mezger and Gerdes (2016). In the Canigó and Roc de Frausa units, they intrude the base of the Canaveilles Group, the so-called Nyer Formation after Álvaro et al. (in press). This formation consists of a micaschist-dominant succession locally punctuated by subsidiary marbles, felsic tuffs and metabasites (Guitard and Laffite 1956; Guitard 1970; Ayora and Casas 1986; Casas et al. 1986; Laumonier et al. 1996, 2004). The Nyer Formation is overlain by the Olette Formation (Álvaro et al. in press), a monotonous shaly succession with interbedded feldspar-rich tuffs (VS2 sensu Laumonier et al. 2015a, b, c). The latter yielded variable $\mathrm{U}-\mathrm{Pb}$ zircon ages, ranging from $575.1 \pm 3.6 \mathrm{Ma}$ in the Puigmal unit (Casas et al. 2015) to $548 \pm 8 \mathrm{Ma}$ in the Roc de Frausa unit, and $560 \pm 11 \mathrm{Ma}$ in the Cap de Creus unit (Castiñeiras et al. 2008). Despite the different U-Pb methods used by the authors, these ages suggest a protracted and episodic volcanic activity throughout the Ediacaran.

In the Puigmal unit, the middle and upper parts of the Olette Formation are marked by the occurrence of metre- to hectometre-thick volcanic and volcanosedimentary units, surrounded and capped by the shale-dominated Jujols Group (Fig. 2). Due to the proliferation of local toponymies to differentiate local lithostratigraphic terms (Laumonier et al. 1996, 2004, 2015a, b, c), we propose to name this volcanic and volcanosedimentary complex the Pic de la Clape Formation (stratotype at its homonymous hill: $42^{\circ} 23^{\prime} 47.64^{\prime \prime} \mathrm{N}$; $2^{\circ} 26^{\prime} 40.99^{\prime \prime} \mathrm{E}$ ), and to subdivide it, from bottom to top, into the Fabert, Finestrelles, and Puig Sec members (Fig. 2).
Their respective names refer to their homonymous stratotypes (Fig. 1b). The Pic de la Clape Formation intertongues northward with monotonous shales and is not recognisable in the Aspres and Conflent tectonostratigraphic units (Fig. 2). As a result, the Canaveilles/Jujols contact is not distinctly identified outside the Puigmal, Vallespir, Roc de Frausa and Albera units.

\section{Materials and methods}

The heterolithic Pic de la Clape Formation has been sampled and studied at seven localities in the Puigmal unit, which are, from west to east: Pic de Finestrelles summit, along the road GIV-5265 in the vicinity of Tregurà village (locality sampled by Casas et al. 2015), the Fabert village, the MollóSetcases transect, the Pic de la Clape and Tour de Mir summits, and the Coll d'Ares pass (Figs. 1, 2).

Geochemical data are based on 17 chemical analyses of representative volcanic samples. The major, trace and rare-earth elements were determined using X-ray fluorescence and inductively coupled plasma mass spectrometry (ICP-MS) at AcmeLabs, Canada. Precision for major, trace and rare elements is usually better than 2, 5-10 and 3-7\%, respectively. ${ }^{147} \mathrm{Sm} /{ }^{144} \mathrm{Nd}$ and ${ }^{143} \mathrm{Nd} /{ }^{144} \mathrm{Nd}$ analyses were carried out at the CAI of Geochronology and Isotopic Geochemistry of the Complutense University (Madrid), using a thermal ionization mass spectrometer (TIMS-Phoenix) with data acquired in multidynamic mode. Isotopic ratios were measured on a subset of whole-rock powders (for a detailed description of the analytical procedure followed in this lab, see Reyes et al. 1997). The isotopic standard for Nd (JNdi1 ) is that of Tanaka et al. (2000). The $2 \sigma$ error of ratios is $\pm 0.006 \%$.

Zircon was separated from fresh volcanogenic samples by rock grinding using a steel crusher. The resulting powders were sieved in the range 50-250 $\mu \mathrm{m}$. Grains were first separated using heavy liquid (sodium heteropolytungstates $2.85 \mathrm{~g} \mathrm{~cm}^{-3}$ density), then using a Frantz magnetic separator. Following Sláma and Košler's (2012) recommendations, the selected grains were obtained from random hand-picking under binocular microscope whatever their size, shape, or colour in order to avoid any operator bias. They were finally set in an epoxy resin puck and polished to expose their core.

$\mathrm{U}-\mathrm{Pb}$ dating of zircon was determined by laser ablation inductively coupled plasma mass spectrometry (LA-ICPMS) at the Geosciences Laboratory in Rennes using a ESI NWR193 UC excimer laser coupled to a 7700× Agilent quadrupole ICP-MS. Details for the operating conditions and the raw data treatment can be found in Manzotti et al. (2015) and in the Supplementary Data 1. All data and analytical results are plotted in Tera-Wasserburg diagrams. Ages were calculated using the Isoplot 3.75 software (Ludwig 2012). 


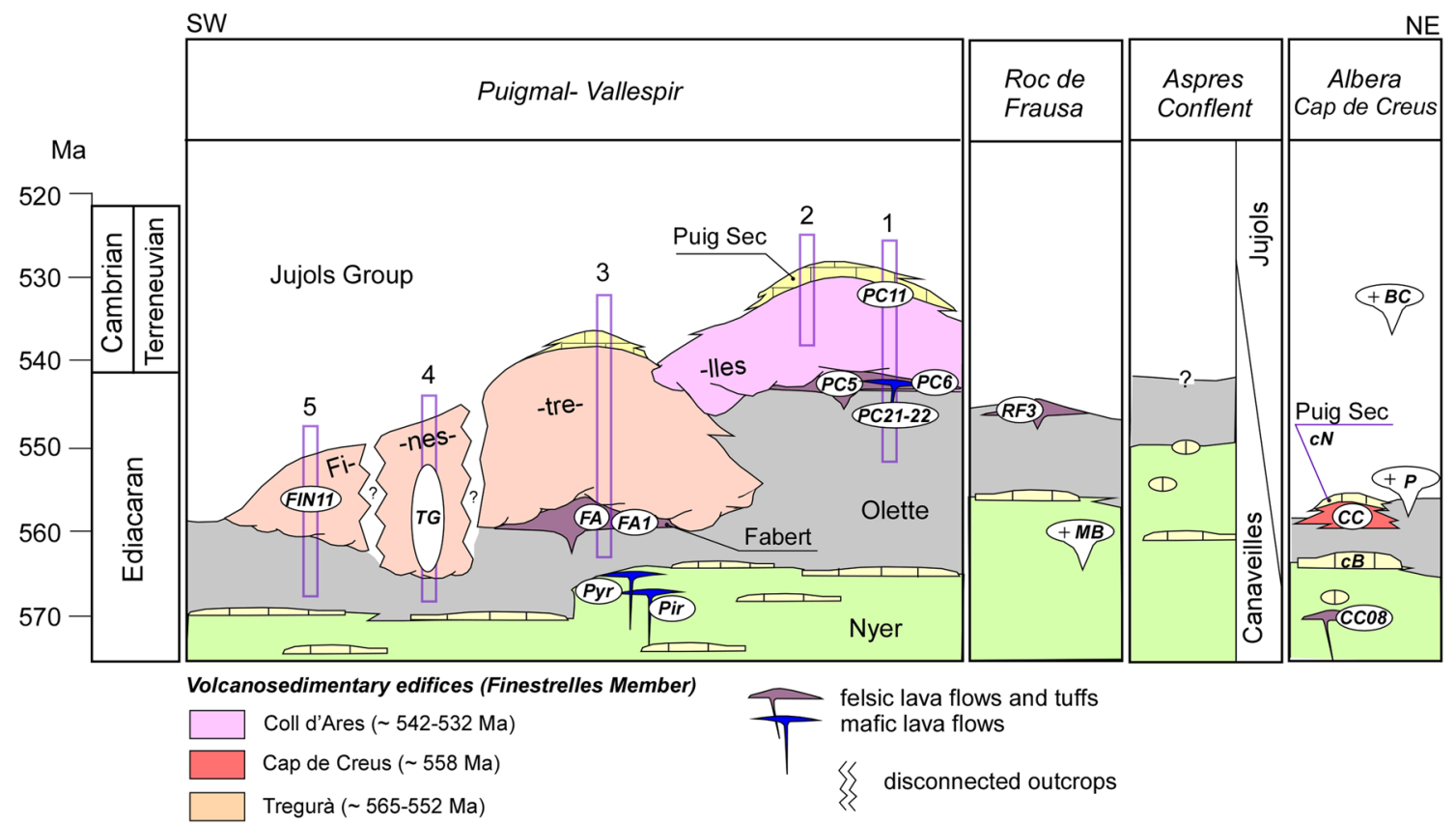

Fig. 2 Chronostratigraphic geometries of the Canaveilles Group in the Variscan/Alpine tectonostratigraphic units of the Eastern Pyrenees, with neither palaeogeographic arrangement nor geochronological setting of granitic gneisses; logs reported in the text: $1-\mathrm{Pic}$ de la Clape, 2-Coll d'Ares/Tour de Mir, 3-Fabert/Molló, 4-Tregurà/ Setcases, 5-Finestrelles; maximum depositional ages of volcaniclastic breccias and orthogneisses: $B C$ Balma Corba gneiss $(533 \pm 3 \mathrm{Ma}$; Laumonier et al. 2015c), $C C$ Cap de Creus volcanosedimentary complex $(560 \pm 11 \mathrm{Ma}$, Castiñeiras et al. 2008; $558 \pm 3 \mathrm{Ma}$; Casas et al. 2015) including breccias from Cap Cerbère and Col d'Oleda, CCO801 Cap de Creus tuff (577 \pm 3 Ma, Casas et al. 2015), FA Fabert metarhyolite at Fabert (559.9 \pm 9.0 Ma, Laumonier et al. 2015b), FA1 Fabert metarhyolite at Fabert $(559.10+1.75 /-1.35 \mathrm{Ma}$, this work),

The mean square weighted deviation (MSWD) is a statistic index that ideally should return a value around 1 in order to consider a date as accurate (Wendt and Carl 1991). If MSWD $>1+2(2 / f)^{1 / 2}$ at $2 \sigma$, where $f$ is the degree of freedom (Wendt and Carl 1991), the calculated date has to be consider as meaningless. In the case of $\mathrm{U}-\mathrm{Pb}$ dating, $f=n-1$, where $\mathrm{n}$ corresponds to the number of analyses used to calculate a date (Spencer et al. 2016).

Probability density plots are built using density plotter (Vermeesch 2004). ${ }^{207} \mathrm{~Pb} /{ }^{206} \mathrm{~Pb}$ ages are used for $\mathrm{U}-\mathrm{Pb}$ analysis giving an age older than $1000 \mathrm{Ma}$ whereas ${ }^{206} \mathrm{~Pb} /{ }^{238} \mathrm{U}$ ages are preferred when the data yield ages younger than $1000 \mathrm{Ma}$. In this study, we kept only the analyses that were $90-110 \%$ concordant for the probability density plots. The depositional ages are only calculated if at least 3 concordant analyses obtained on three different grains return the same apparent age within error, as proposed by Dickinson and Gehrels (2009), in order to ensure a statistically robust estimate of the maximum depositional ages. In sedimentary rock samples, about 110 grains were analysed to get the
FIN11 Finestrelles Member at Finestrelles summit $(556.0 \pm 6.9 \mathrm{Ma}$, this work), $M B$ Mas Blanc gneiss $(560.1 \pm 7.2 \mathrm{Ma}$, Castiñeiras et al. 2008), $P$ Port gneiss (553.0 $\pm 4.4 \mathrm{Ma}$, Castiñeiras et al. 2008), PC5 Finestrelles Member at Pic de la Clape summit (542.9+5/- 1.3 Ma, this work), PC11 Fabert metarhyolite at Pic de la Clape summit $(532.9 \pm 6 \mathrm{Ma}$, this work), RF3 $548.4 \pm 8.4 \mathrm{Ma}$ (Castiñeiras et al. 2008); $T G$ Finestrelles Member at Tregurà $(575 \pm 4,570 \pm 10$ and $568 \pm 6 \mathrm{Ma}$; Casas et al. 2015) recalculated at $565 \pm 9,559 \pm 9$ and $552 \pm 10 \mathrm{Ma}$, respectively (this work); PC, Pir, Pyr samples referred to in the text and selected for geochemical analyses, $c B$ col de Banyuls marble, $c N$ Cap Norfeu marble; sample GRAl from the Vallespir unit $(580 \pm 10 \mathrm{Ma}$, Cocherie et al. 2005) in need of revision and not represented here

best representativity of the detrital zircon populations. For the volcanic samples, more than 50 grains were analysed, following Bowring et al.'s (2006) suggestion. Ages of tuffs were calculated using the TuffZirc Age algorithm (Ludwig and Mundil 2002) and compared with their respective concordia ages.

\section{Facies associations}

As stated above, the Pic de la Clape Formation is a heterolithic succession composed, from bottom to top, of the Fabert, Finestrelles and Puig Sec members (Fig. 2). Despite their moderate to strong Variscan deformation and greenschist-to-amphibolite facies metamorphic overprint, primary fabrics and textures remain locally preserved. Their facies and sedimentological interpretations are documented below. 


\section{Fabert Member}

The Fabert Member consists of bedded metarhyolites, up to $50 \mathrm{~m}$ thick. Initially described by Guitard and Laffite (1956), they crop out in the Puigmal unit, from the vicinity of Fabert village to the Pic de la Clape summit. Initially named "gneiss granulé" by Guitard and Laffite (1956), Guitard (1970) described this unit as a metamorphic rock derived from a volcanic or volcanosedimentary protolith, displaying a lapilli structure and a high-to-medium content in $\mathrm{SiO}_{2}(\sim 64 \%$; Guitard 1970). Subsequently, the term "gneiss granulé" has been broadly used for the description of these and other felsic volcanosedimentary levels with similar macroscopic aspect interbedded within the Canaveilles Group (Ayora and Casas 1986; Casas et al. 1986; Cirés et al. 1995; Laumonier et al. 1996, 2004).

The lenticular-shaped rather massive rock-unit intertongues toward NE and SW with shales. At the Pic de la Clape summit, it contains rare intraformational breccia, fine- to medium-grained arkose, black shale and basic lava flow interbeds. The latter are the source of some mafic clast lags lining scouring contacts. Similar metarhyolites, including some metabasite interbeds, have been described in the underlying Nyer and Olette formations of the Canaveilles Group, but their age and relationship with their host rock remain uncertain (Ayora and Casas 1986; Casas et al. 1986; Navidad et al. 1996; Navidad and Carreras 2002; Castiñeiras et al. 2008). Although some massive and lenticular exposures exhibit features of a rhyolitic dome emplacement, the Fabert Member may locally represent fallout deposits that accumulated with minor local soft-sediment deformation. They accumulated too rapidly to allow ash to settle from the water column or be redistributed. In contrast, the subsidiary breccia and arkose interbeds represent interruptions by lesser debris-flow and substrate remobilization. The shale interbeds mark inter-eruptive, background sedimentation.

\section{Finestrelles Member}

The Finestrelles Member is heterolithic and up to $500 \mathrm{~m}$ thick in the Puigmal unit. It is not stratiform but displays an irregular geometry: its base (para)conformably overlies either the Olette Formation or the Fabert Member, and its top is onlapped by both the Puig Sec Member and the Jujols Group (Fig. 2). The member is a volcanosedimentary complex made up of volcaniclastic breccia, tuffaceous sandstone and siltstone, and is locally punctuated by shale, litharenite and pristine-to-volcaniclastic limestone interbeds (Fig. 3ac). Thicker beds are dominated by volcaniclastic breccia, whereas the remaining facies are more abundant in the thinner lenses.

Lithofacies and their distribution are overall heterogeneous, with exposures characterised by varying compositions and facies, interlayered on a 10-100 m scale and displaying complex interfingering relationships. Heterolithic volcaniclastic breccias are the most characteristic facies, which typically occur as thick $(>10 \mathrm{~m})$, matrix-supported and structureless units separated by thin $(<1 \mathrm{~m})$ clast-supported volcaniclastic breccias, and tuffaceous sandstones and siltstones. Breccias ( $>25 \%$ blocks) contain angularto-subrounded volcaniclasts, centimetric to pluridecimetric in size. Clasts are polygenic and dominated by unsorted, composite (polyphasic) volcaniclasts, although carbonate, sandy and shaly clasts are locally abundant. The tuffaceous matrix is rich in subrounded quartz and feldspar-rich siltstone, irregularly cemented with sparry calcite and dolomite (Fig. 3d-f). Rusty rhyolitic clasts are common in the lower part of the member suggesting local reworking and erosion of a rhyolitic basement (Fabert Member).

Despite the massive aspect of the breccias, distinct intrabreccia scouring contacts are locally common, although their respective chronostratigraphic gaps are uncertain. They are capped by heterolithic lags exhibiting normal grading. The sharp scouring base of some breccias and litharenitic sandstones is highlighted by the presence of rip-up clasts sourced from interbedded shales. At the Pic de Finestrelles summit, some metre-scale volcaniclastic breccia and tuffaceous sandstone strata fine upward and are interrupted by laminated shale interbeds, up to $0.5 \mathrm{~m}$ thick. Fine- to medium-grained litharenitic interbeds are poorly sorted, lenticular in shape and display cross- to low-angle stratification and parallel laminae (Fig. 3c). In the vicinity of Tregurà village and at Pic de Finestrelles summit, several decimetre-thick interbeds are volcaniclastic-rich to pristine sparry limestones, grading both laterally and vertically into litharenites rich in sparry (poikilotopic) calcite and dolomite cement. In the same areas, the uppermost part of the member contains subrounded carbonate granules and boulders (up to $2 \mathrm{~m}$ in size) "floating" in a shaly-to-tuffaceous matrix (Fig. 3g). Some carbonate boulders show injection dykes infilled with host sediment. In contrast, between Fabert village and the Pic de la Clape summit, the volcanoclastic breccias and tuffaceous sandstones are free of carbonate matrix and clasts. Glassy textures (fiammes or shards) have been locally described near Tregurà (Casas et al. 2015).

The dominant massive and structureless, matrix-supported fabric of the Finestrelles Member, containing poorly sorted, angular to subrounded, polygenic and polyphasic clasts, and local presence of mafic and rusty rhyolitic clasts are consistent with a deposition from volcaniclastic debris flows. The fluidal-pumiceous or amoeboid clasts and fiammes described by Casas et al. (2015) inside some volcanoclastic breccias are considered as characteristic of high-temperature emplacement of pyroclastic deposits (Bull and McPhie 2007). Carbonate boulders displaying injection dykes infilled with host sediment attest that these clasts were 

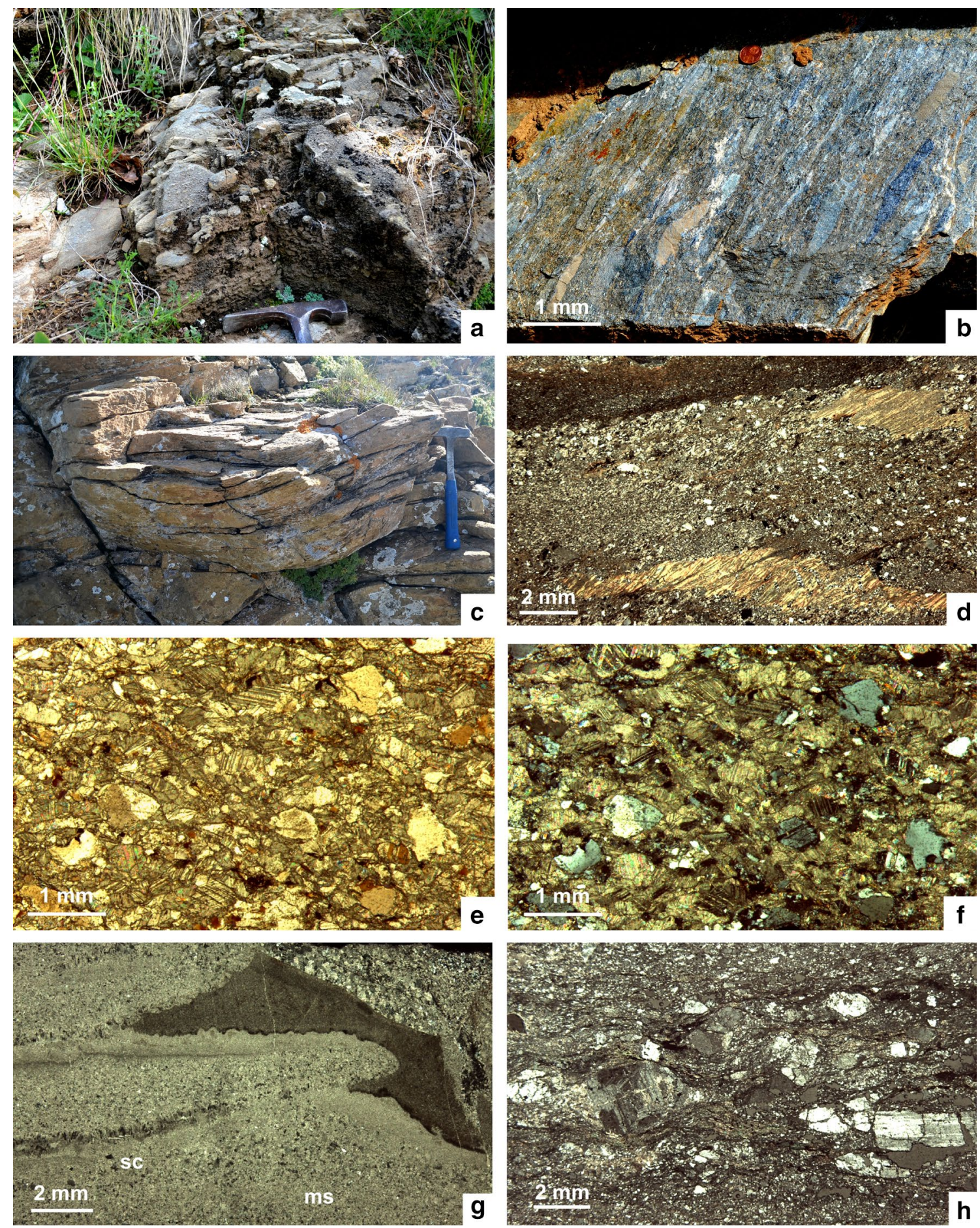

Fig. 3 a Weathered breccias of the Finestrelles Member at Tregurà village. $\mathbf{b}$ Field aspect of the Finestrelles unsorted breccias at Tregurà village (d, e) and Finestrelles summit (f). c Trough cross-stratified sets of tuffaceous sandstones at the Finestrelles stratotype. d Thinsection photomicrograph of schist clasts derived from the underlying Olette Formation exhibiting crenulated cleavage and embedded in a tuffaceous silty matrix at Tregurà village. e, f Sparry limestone com-

prising scattered quartz and feldspar phenocrysts at Finestrelles summit; parallel light and cross polarised light, respectively. g Limestone granule showing alternations of microsparite (ms) and sparry crusts, partially surrounded by micrite $(\mathrm{m})$, encased in a volcanosedimentary matrix (v); Finestrelles. h Feldspar-rich tuff ("granulé") embedded in shales at Finestrelles summit 
not yet lithified during deposition. Although the presence of euhedral or broken single crystals suggests that these deposits were originally deposited as pyroclastic debris (Fig. 3h), the final facies association points to reworking before their definitive subaqueous deposition.

Such kind of syneruptive, resedimentary ("cannibalistic") deposition reflects slope-related, downslope instability from the site of eruption and episodes of mass-wasting volcanic explosive eruptions. Dominance of volcaniclastic debris in resedimentary syneruptive units with abrupt vertical and lateral facies changes and their overall poorly bedded nature prone to mass-wasting and reworking of pyroclastic debris. Slope aprons may be associated with active syndepositional faulting in the vicinity of volcanic centres recording alternation of explosive (felsic) and calm (mafic) emplacements in a marine setting.

The presence of both interbedded pristine-to-volcaniclastic limestones and tuffaceous sandstones rich in calcite/dolomite cements points to episodic development of carbonate productivity, subsequently interrupted by syneruptive pulsations. Locally, the Finestrelles Member contains reworked (subrounded) carbonate granules and boulders linked to the contemporaneous development of carbonate factories leading to the onset of irregular palaeoreliefs capped by centres of carbonate production (both older and laterally equivalent to the carbonate-dominated Puig Sec Member, described below), then destabilized by tectono-volcanic events and included in the debris avalanche deposits.

\section{Puig Sec Member}

The member, up to $180 \mathrm{~m}$ thick, consists of massive to bedded, locally dolomitized limestones and marbles. It appears in the Puigmal unit, from Molló village to Pic de la Clape summit (Fig. 1b). The main features are the abundance of fenestral and birdseye-rich fabrics (with primary porosities cemented by drusy and equant calcite cements) interrupted by polygonal mudcracks and tepee structures infilled with brownish silty sediment (Fig. 4a-c). Karstic pockets infilled with brownish marlstones rich in illite (after XRD analysis) and intraformational breccia, crosscut with synsedimentary fissuring, are significant in the Coll d'Ares pass and the Pic de la Clape and Tour de Mir summits (Fig. 4d-g). Subsidiary sparry layers and peloidal-intraclastic wackestones/ packstones show parallel to low-angle laminae. Microstromatolitic lamination is locally interrupted by clotted textures mimicking complex cauliflower-like microbial textures (Fig. 4h). In contrast, in the lower part of Coll d'Ares pass and in the vicinity of Molló village, the bedded limestones display interbedded lenses with scouring contacts and grading of intraclastic rip-up clasts, up to $1.2 \mathrm{~m}$ thick. These beds exhibit trough and planar cross-bedding, and low-angle and parallel laminae.
This facies association represents the establishment of peritidal environments, rich in microbial mats and biofilms, episodically submitted to subaerial exposure, karstic emplacement and synsedimentary fissuring; fenestrae and birdseyes are interpreted as a release of fluids by organic decay. The interbedded limestones found in Molló village and the lower part of Coll d'Ares pass point to episodic development of shoal barriers protecting the peritidal environments. As a result, a retrogradational trend of shoal barrier complexes protecting (back-barrier) peritidal environments can be suggested migrating centripetally throughout elevated areas of the composite palaeoreliefs formed by the above-reported Finestrelles Member.

\section{Magmatic affinity of volcanic products}

Seventeen new geochemical analyses from the entire Canaveilles Group (Table 1) are compared with those reported by Navidad et al. (1996) for the Roc de Frausa and Navidad and Carreras (2002) for the Canigó units, sampled across the Nyer and Olette formations (in the figures, these samples are referred to Nyer-Olette*). Unfortunately, the stratigraphic control of some samples analysed in the latter works is not well constrained and complete descriptions about their relationship with the host rock (lava flow, sill or dyke) and their pre-, syn- or post-Sardic setting are not available. As a result, the dataset of Navidad et al. (1996) and Navidad and Carreras (2002) should be considered with caution. Geochemical analyses from the Nyer Formation of the Cap de Creus unit (Casas et al. 2015) are referred in the figures to Nyer**. In order to check the validity of published data, we sampled again the lower part of the Canaveilles Group in the Roc de Frausa unit (samples Pir and Pyr).

\section{Mafic rocks}

Metabasites are represented by some basalt and basaltic andesite lava flows and sills interbedded in the Nyer Formation and the lower part of the Olette Formation from the Puigmal, Roc de Frausa and Cap de Creus units, and a basaltic andesite (according to the classification of immobile elements; Pearce 1996) embedded within the Fabert Member at the Pic de la Clape summit (PC6 in Fig. 5a). In this diagram, all samples plot in the subalkaline field (Fig. 5a). $\mathrm{SiO}_{2}$ content ranges from 41 to $54 \mathrm{wt} \%$ (samples with $\mathrm{SiO}_{2}$ values $>52 \%$ are included because alteration may have masked their original composition). The Nyer, Nyer** and Nyer-Olette* sets are metaluminous (A/CNK $=0.81$ and 0.76 , respectively), whereas the Fabert set is peraluminous $(\mathrm{A} / \mathrm{CNK}=2.63)$.

Following the AFM diagram of Irvine and Baragar (1971), most mafic samples plot in the tholeiitic field 

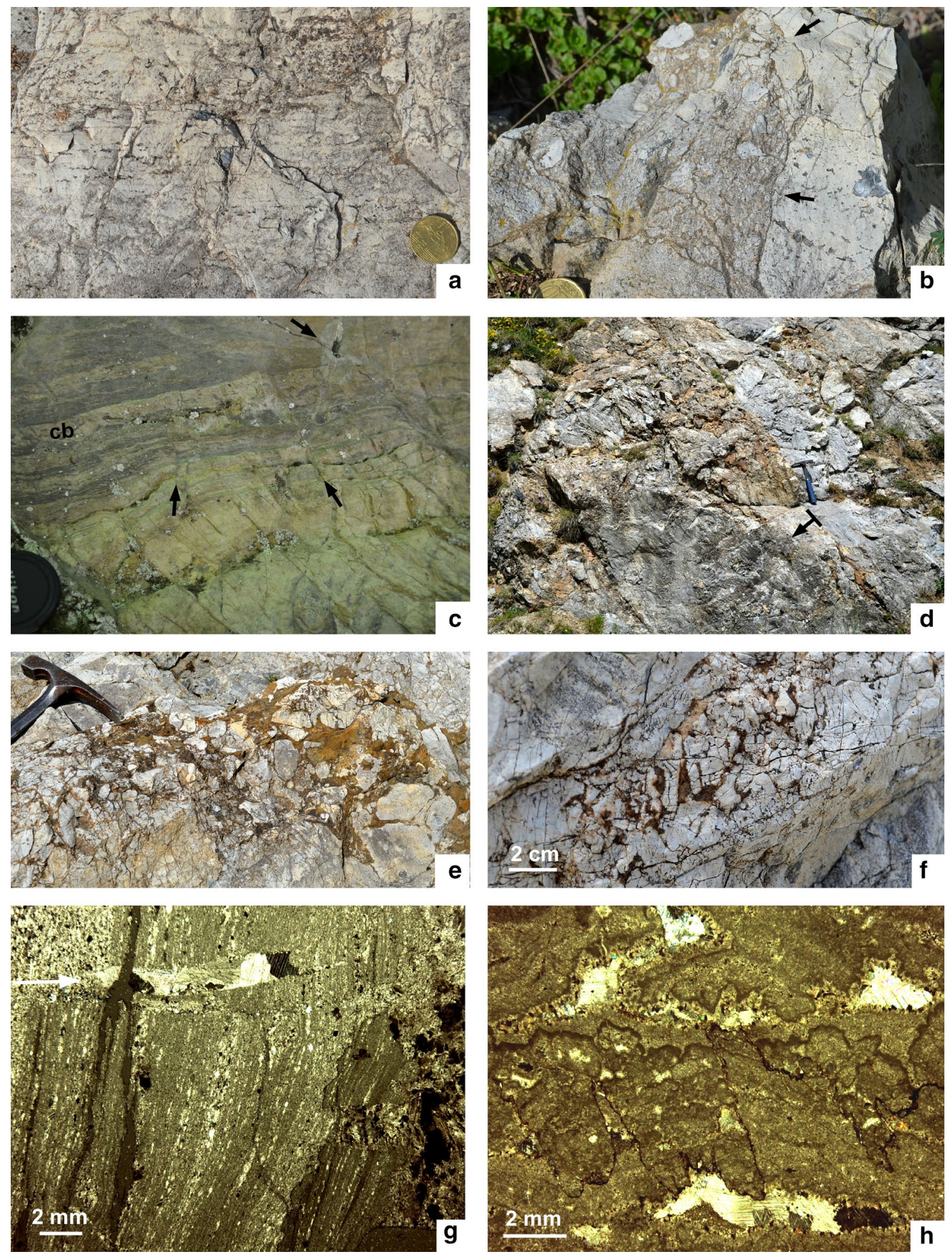

Fig. 4 Sedimentary structures preserved in the Puig Sec member at its stratotype of Coll d'Ares. a Fenestral limestone exhibiting parallel laminae. b Fenestral limestone with disturbed pockets (false orange) infilled with contorted and intraformational breccia. c Arrowed contact of breccia infill crosscutting the pristine fenestral limestone. d Karstic cavity complex of the Puig Sec Member at its stratotype of Coll d'Ares with sealed top (arrowed) and lower digitations. e, f Brec-

cia-to-conglomerate intraformational infill. g Thin-section photomicrograph of microstromatolitic laminations alternating with peloidal packstones, overlying intraformational breccias and locally affected (g) by synsedimentary fissuring; top on the left. h Thin-section photomicrograph of microbial limestones from the Puig Sec Member at Tour du Mir section with clotted textures outlined with microbial crusts (darker) forming cauliflower-like fabrics 


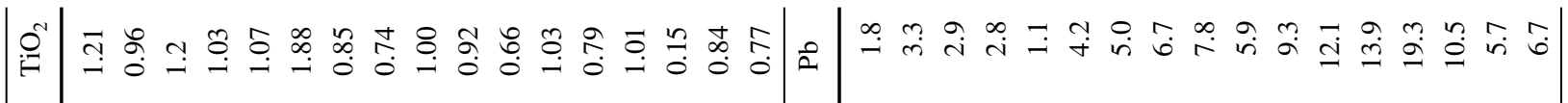
赵

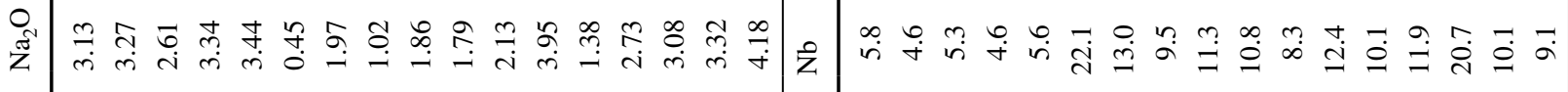

융ำ

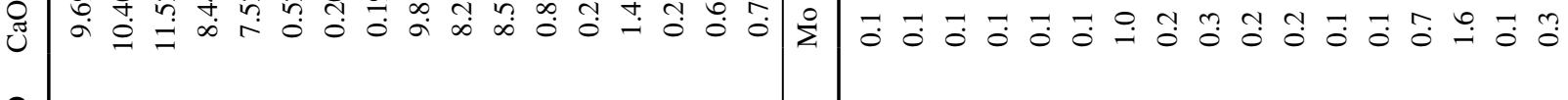
央 虽

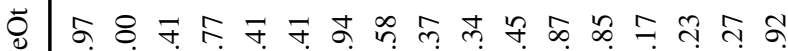

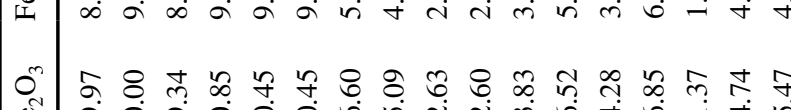
平

○) तิ ซำ

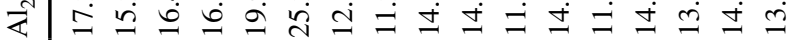

人)

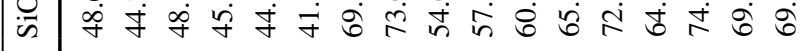

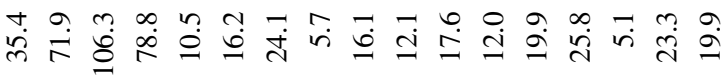

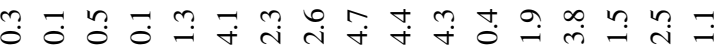
U 若

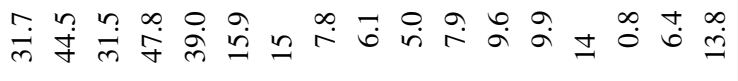

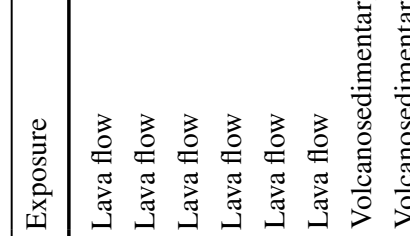
焉

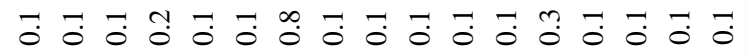

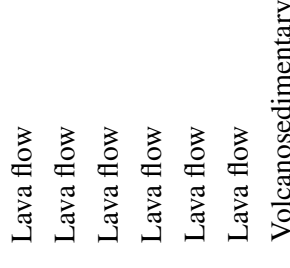

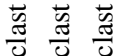
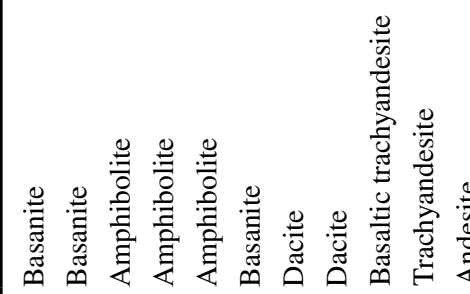

\section{竞}

$\vec{n}$

$\overrightarrow{0} \overrightarrow{0} \overrightarrow{0} \overrightarrow{0} \overrightarrow{0} \overrightarrow{0} \overrightarrow{0} \overrightarrow{0} \overrightarrow{0} \overrightarrow{0} \overrightarrow{0} \overrightarrow{0} \overrightarrow{0} \overrightarrow{0} \overrightarrow{0} \overrightarrow{0} \overrightarrow{0}$

ขึ

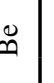

ข็

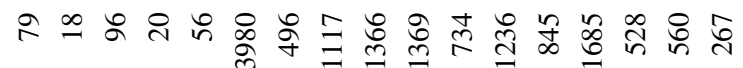

₹

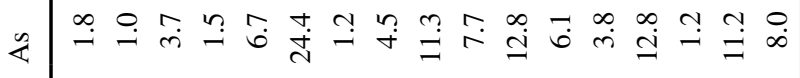

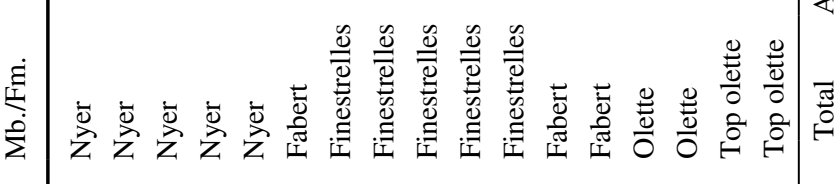

य $\overrightarrow{0} \overrightarrow{0} \overrightarrow{0} \overrightarrow{0} \overrightarrow{0} \overrightarrow{0} \overrightarrow{0} \overrightarrow{0} \overrightarrow{0} \overrightarrow{0} \overrightarrow{0} \overrightarrow{0} \overrightarrow{0} \overrightarrow{0} \overrightarrow{0} \overrightarrow{0} \overrightarrow{0}$

ㅊำ

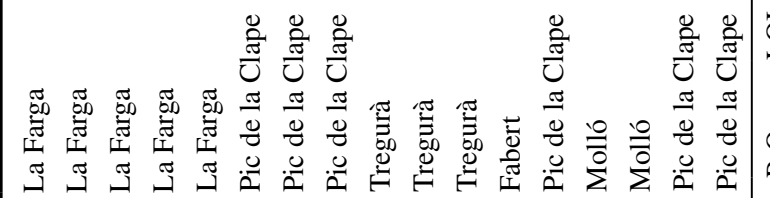

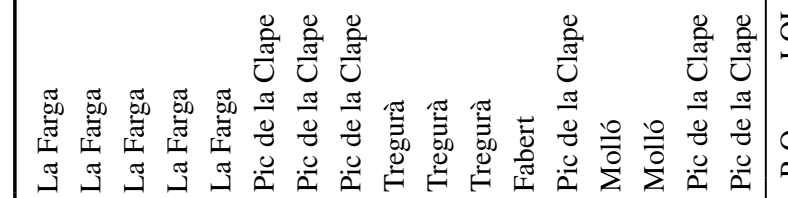
๙

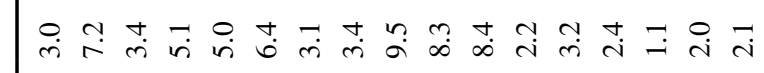
(1)

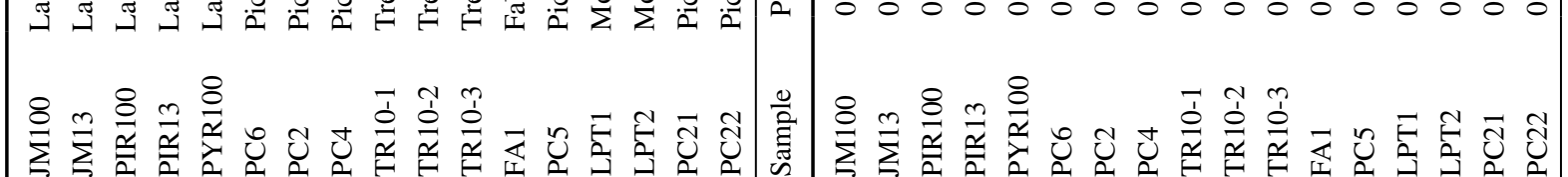




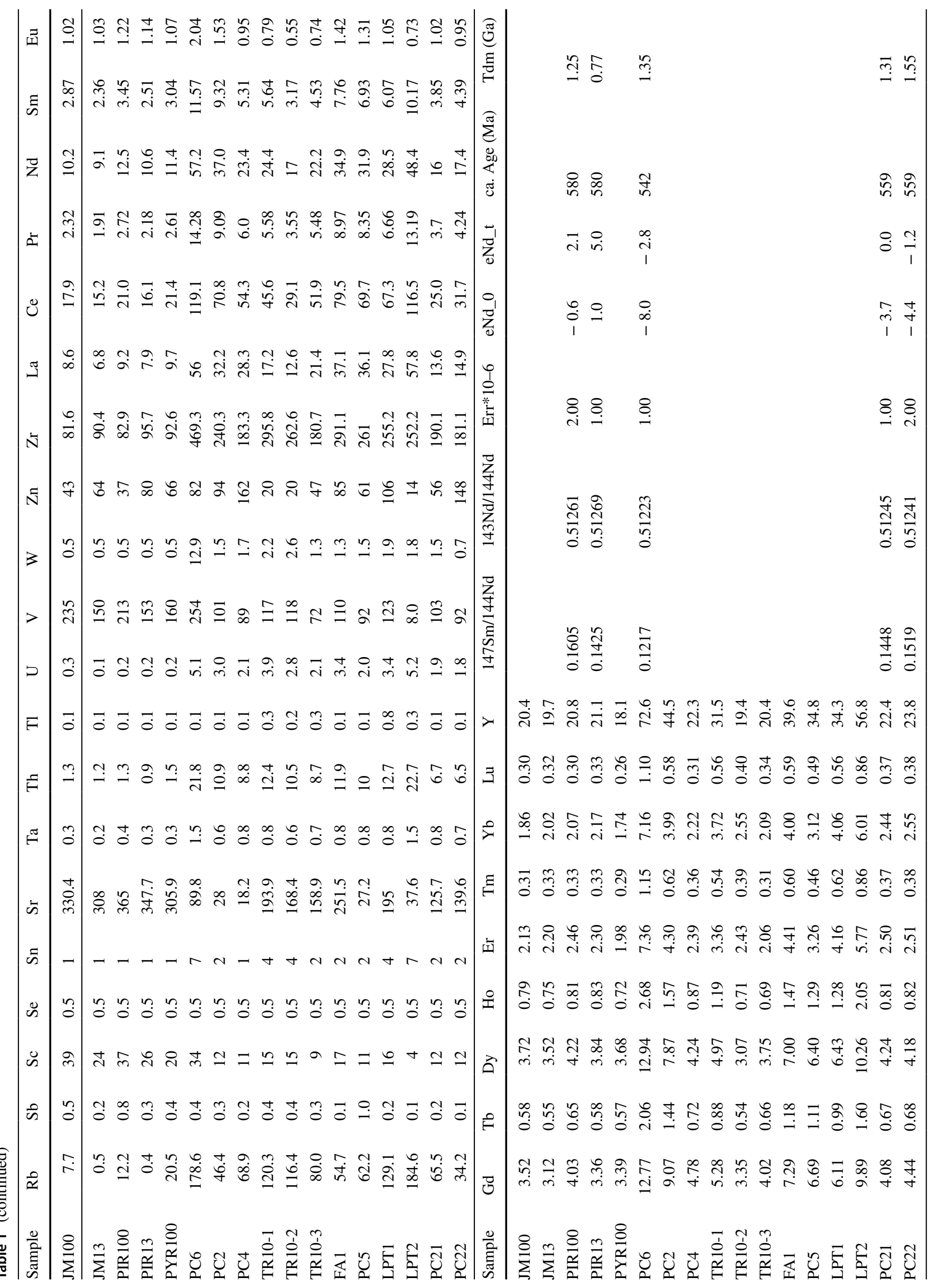


a

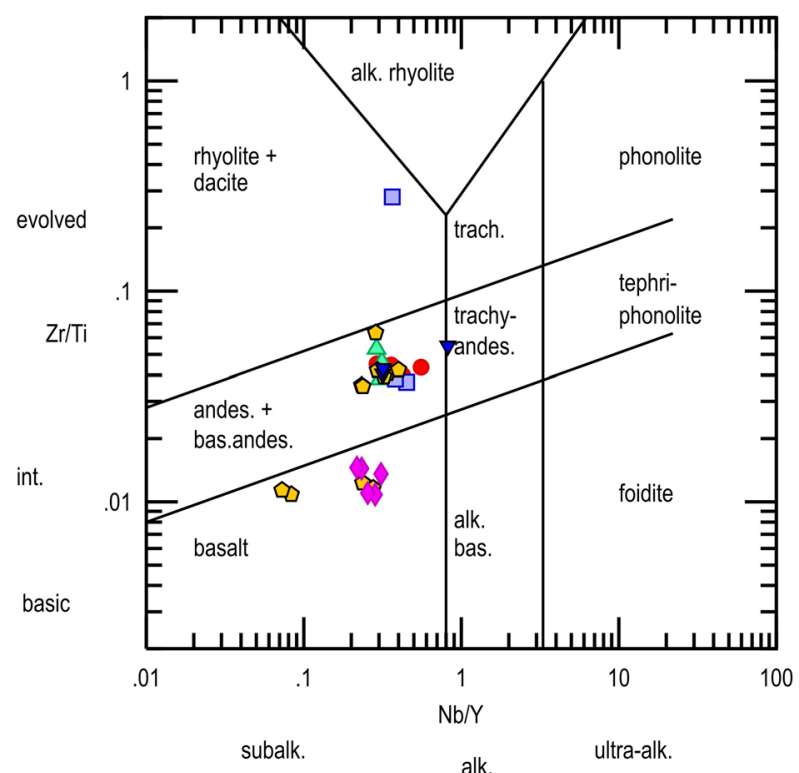

Fig. 5 Geochemical features of the Ediacaran rocks from the Canaveilles Group, Eastern Pyrenees. a Petrological classification of Pearce (1996; modified from Winchester and Floyd 1977) based on immobile elements. b AFM diagram of Irvine and Baragar (1971)

(Fig. 5b), whereas sample PC6 (Fabert Member) plots in the calc-alkaline field, and some samples from the Nyer-Olette* set in both fields. A chondrite-normalised plot of basalts (Sun and McDonough 1989) reveals a subdivision of the dataset into two assemblages (Fig. 6a): one with less LREE fractionation (Nyer set) and another one displaying higher fractionation features including the Fabert basaltic andesite and the basalts from Nyer-Olette*. The Nyer assemblage b

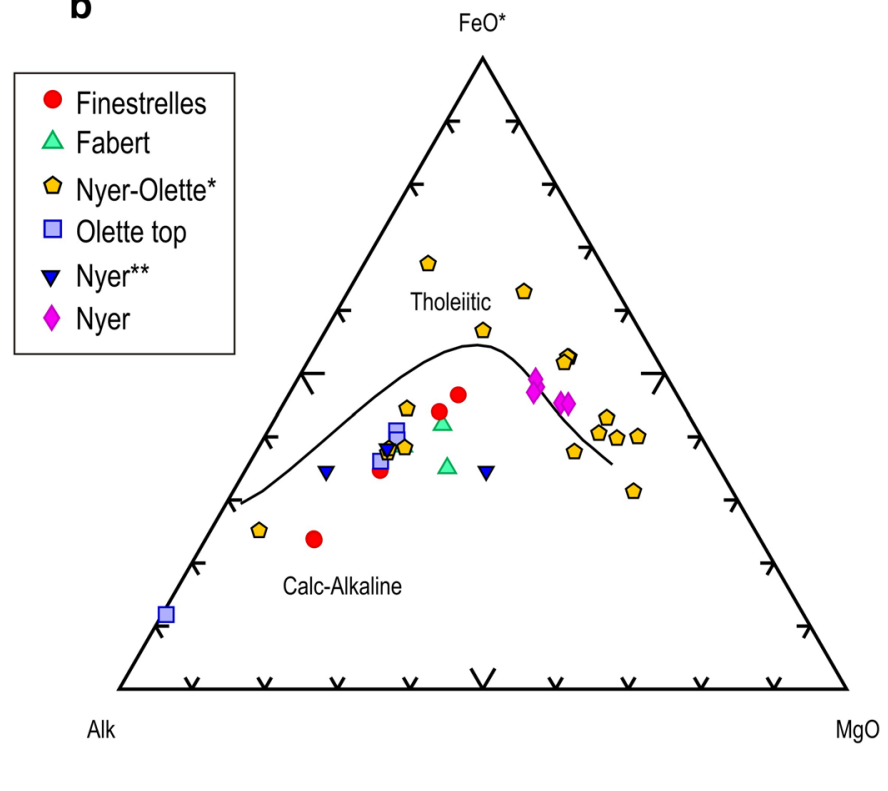

that allows distinction between calc-alkaline and tholeiitic magmatic series; (*) Nyer and Olette formations from Roc de Frausa (Navidad et al. 1996; Navidad and Carreras 2002), (**) Nyer Formation from Cap de Creus (Casas et al. 2015)

shows moderate fractionation of LREE/HREE with average $(\mathrm{La} / \mathrm{Sm})_{n}=1.86$ and $(\mathrm{Gd} / \mathrm{Yb})_{n}=1.44$, and no Eu anomalies $\left(\mathrm{Eu} / \mathrm{Eu}^{*}=1.07\right)$ suggesting little plagioclase fractionation. The Nyer-Olette* assemblage shows similar average values of $(\mathrm{La} / \mathrm{Sm})_{n}=1.68$ and, $(\mathrm{Gd} / \mathrm{Yb})_{n}=1.37$ and lower fractionation patterns of plagioclase with $\mathrm{Eu} / \mathrm{Eu}^{*}=0.92$. The Fabert Member displays greater LREE fractionation patterns with average $(\mathrm{La} / \mathrm{Sm})_{n}=3.02$ and $(\mathrm{Gd} / \mathrm{Yb})_{n}=1.44$, which

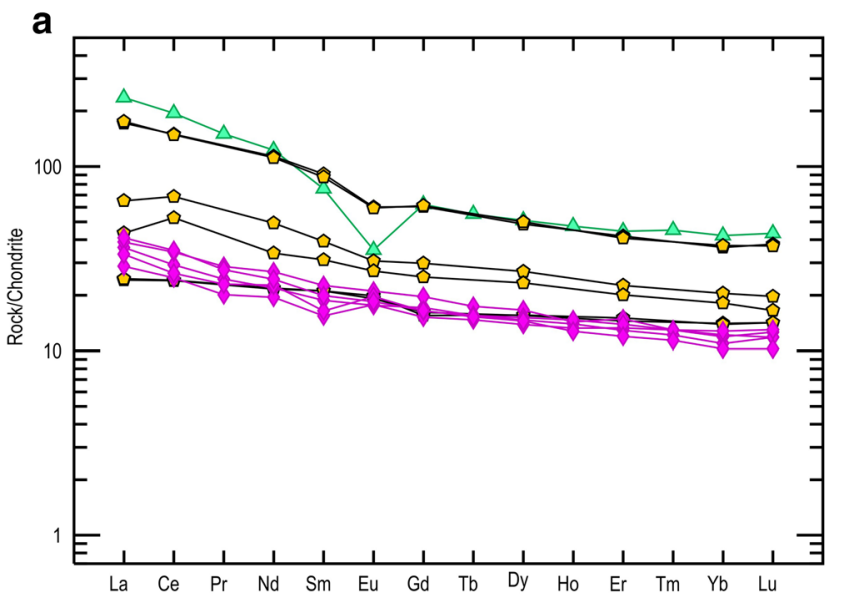

b

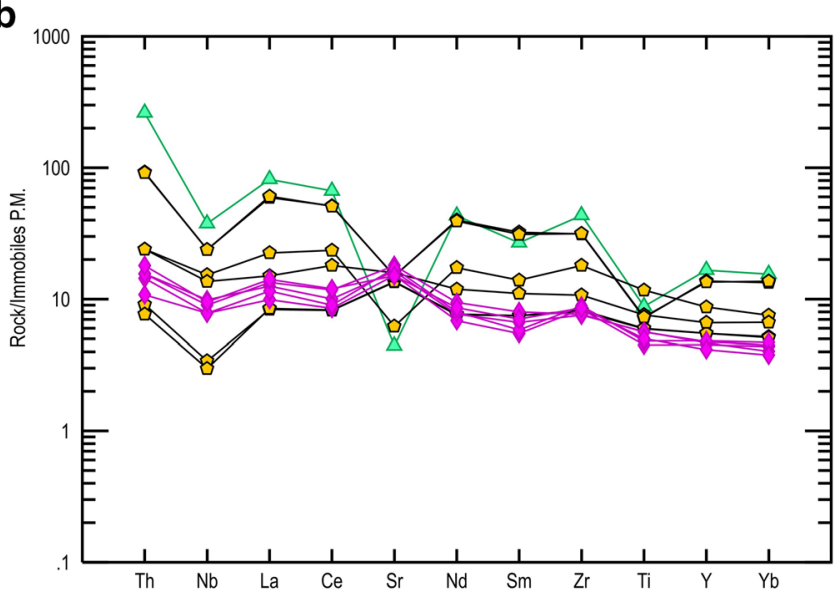

$\triangle$ Fabert $\square$ Nyer-Olette ${ }^{*}$ Nyer

Fig. 6 a Chondrite-normalised REE patterns (normalised to Sun and McDonough 1989) for Ediacaran mafic rocks. b Multi-element diagram normalised to Primitive Mantle of Palme and O'Neill (2004) for Ediacaran mafic rocks; legend as Fig. 5 
may indicate crustal participation in the magmatic source. The nearly flat pattern exhibited by the HREE chondritenormalised dataset of all samples suggests an intermediate crustal source, without garnet.

In the multivariate (or spider-diagram) diagram (Fig. 6b), all samples display a negative anomaly in $\mathrm{Nb}$, which could indicate crustal participation in its genesis. The Fabert Member and the Nyer-Olette* assemblage show negative anomalies in $\mathrm{Sr}$, indicating plagioclase fractionation, whereas the Nyer samples show positive anomalies suggesting no plagioclase fractionation in the melt. This difference may indicate a greater crustal participation in the evolution of the source magmas for the Fabert Member and the Nyer-Olette* assemblage than in the Nyer association.

The volcanism of the Fabert Member displays values close to the Upper Continental Crust (UCC) of Rudnick and Gao (2004) in the $\mathrm{La} / \mathrm{Nb}, \mathrm{Th} / \mathrm{Nb}, \mathrm{Th} / \mathrm{La}$ and $\mathrm{Th} / \mathrm{Yb}$ ratios, but values close to the Lower Continental Crust (LCC) in the $\mathrm{La} / \mathrm{Yb}, \mathrm{La} / \mathrm{Sm}, \mathrm{Nb} / \mathrm{Y}, \mathrm{Zr} / \mathrm{Nb}, \mathrm{Th} / \mathrm{Yb}$ and $\mathrm{Nb} / \mathrm{Yb}$ ratios (Fig. 7a), reflecting a possible crustal contamination at their origin. In contrast, the Nyer assemblage is closer to the Lower Continental Crust of Rudnick and Gao (2004), whereas the $\mathrm{La} / \mathrm{Yb}, \mathrm{La} / \mathrm{Sm}$ and $\mathrm{Gd} / \mathrm{Yb}$ ratios are close to enriched sources (EMORB of Sun and McDonough 1989). The Nyer-Olette* assemblage also presents values closer to LCC but with some variations: they show enrichments for the $\mathrm{Eu} / \mathrm{Eu}^{*}$ and $\mathrm{La} / \mathrm{Nb}$ ratios and depletions for the $\mathrm{Nb} / \mathrm{Y}$ and $\mathrm{Nb} / \mathrm{Yb}$ ratios (see Fig. 7a; Table 1).

In the tectonic discrimination diagram after Wood (1980) (Fig. 8a), all the basic members plot in the arc-basalt domain. In the $\mathrm{Th} / \mathrm{Yb}$ vs. $\mathrm{Nb} / \mathrm{Yb}$ tectonic discriminant diagram after Pearce (2008) (Fig. 8b), a crustal input via subduction into the source of melts may be suggested, represented by an array displacement to higher $\mathrm{Th} / \mathrm{Nb}$ ratios. The Fabert sample (PC6) is displaced toward a more continental field. Finally, in the $\mathrm{TiO}_{2} / \mathrm{Yb}$ vs. $\mathrm{Nb} / \mathrm{Yb}$ diagram (Pearce 2008; Fig. 8c), the Fabert sample shows an E-MORB affinity, whereas the remaining samples (Nyer and most of Nyer-Olette* samples) display greater $\mathrm{TiO}_{2} / \mathrm{Yb}$ ratios that could indicate deeper melting.

\section{Felsic and intermediate rocks}

Rocks of felsic to intermediate composition represent the most abundant and extensive manifestation of the Cadomian magmatism in the Pyrenees. They are located in the uppermost part of the Nyer Formation (including the Nyer* and Nyer-Olette* dataset) and in the Fabert and Finestrelles members (Pic de la Clape Formation) of the Cap de Creus and Puigmal units. They are oversaturated in $\mathrm{SiO}_{2}$ with contents ranging from 54 to $75 \mathrm{wt} \%$ (Table 1). Most of them are peraluminous, with $\mathrm{A} / \mathrm{CNK}$ ratios varying between 1.00 (Nyer-Olette*) and 1.71 (Fabert Member). These rocks
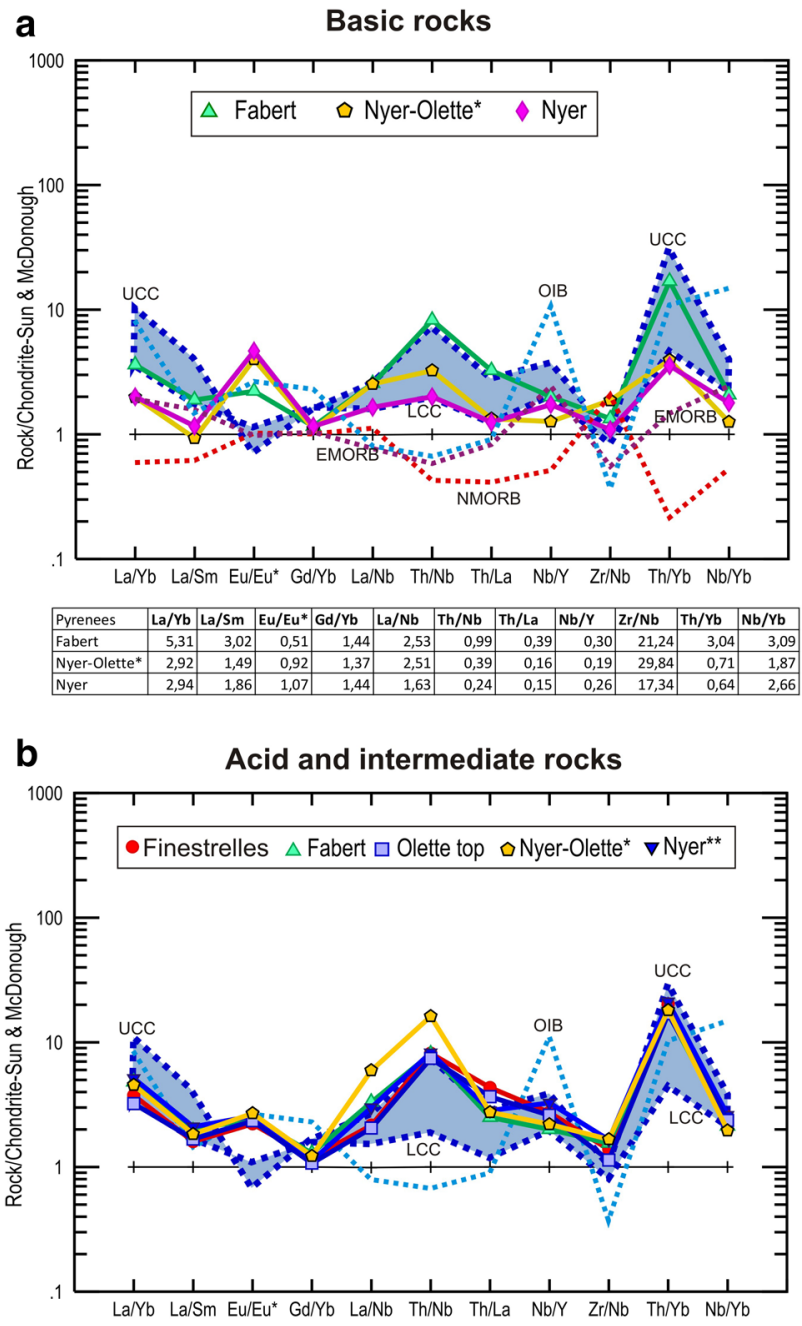

\begin{tabular}{|l|l|l|l|l|l|l|l|l|l|l|l}
\hline Pyrenees & $(\mathrm{La} / \mathrm{Yb}) \mathrm{n}(\mathrm{La} / \mathrm{Sm}) \mathrm{n}$ Eu/Eu* $(\mathrm{Gd} / \mathrm{Yb}) \mathrm{n} \mid \mathrm{La} / \mathrm{Nb}$ & $\mathrm{Th} / \mathrm{Nb}$ & $\mathrm{Th} / \mathrm{La}$ & $\mathrm{Nb} / \mathrm{Y}$ & $\mathrm{Zr} / \mathrm{Nb}$ & $\mathrm{Th} / \mathrm{Yb} / \mathrm{Nb} / \mathrm{Yb}$ \\
\hline
\end{tabular}

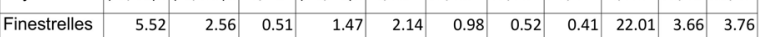
\begin{tabular}{|l|r|r|r|r|r|r|r|r|r|r|r|}
\hline Fabert & 7.08 & 3.12 & 0.57 & 1.60 & 3.28 & 0.97 & 0.30 & 0.30 & 24.66 & 3.09 & 3.17 \\
\hline
\end{tabular} \begin{tabular}{|l|l|l|l|l|l|l|l|l|l|l|l|}
\hline Olette top & 4.74 & 2.68 & 0.54 & 1.33 & 2.03 & 0.89 & 0.44 & 0.39 & 18.09 & 3.05 & 3.52 \\
\hline
\end{tabular} \begin{tabular}{|r|r|r|r|r|r|r|r|r|r|r|r|} 
Nyer-Olette $^{*}$ & 6.68 & 2.94 & 0.62 & 1.52 & 5.89 & 1.94 & 0.33 & 0.33 & 26.53 & 3.26 & 2.92 \\
\hline Nyer $^{4}$ & 7.56 & 3.37 & 0.59 & 1.39 & 2.97 & 0.99 & 0.34 & 0.49 & 26.28 & 3.80 & 3.88 \\
\hline
\end{tabular} \begin{tabular}{|l|l|l|l|l|l|l|l|l|l|l|l|}
\hline Nyer $^{* *}$ & 7.56 & 3.37 & 0.59 & 1.39 & 2.97 & 0.99 & 0.34 & 0.49 & 26.28 & 3.80 & 3.88 \\
\hline
\end{tabular}

References

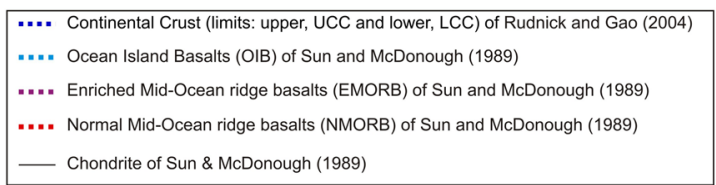

Fig. 7 Chondrite-normalised isotope ratio patterns (Sun and McDonough 1989) for standard comparison. a Mafic rocks. b Felsic and intermediate rocks. Blue area: limits of continental crust values (Lower and Upper) of Rudnick and Gao (2004); legend as Fig. 5

plot in the subalkaline field of the Pearce's (1996) diagram (Fig. 5a), and in the calc-alkaline field of Irvine and Baragar (1971) (Fig. 5b).

In the chondrite normalised diagram of Sun and McDonough (1989), the Fabert and Nyer** data present the most fractionated values, with $(\mathrm{La} / \mathrm{Sm})_{n}$ average $=3.12$ and 3.37, 

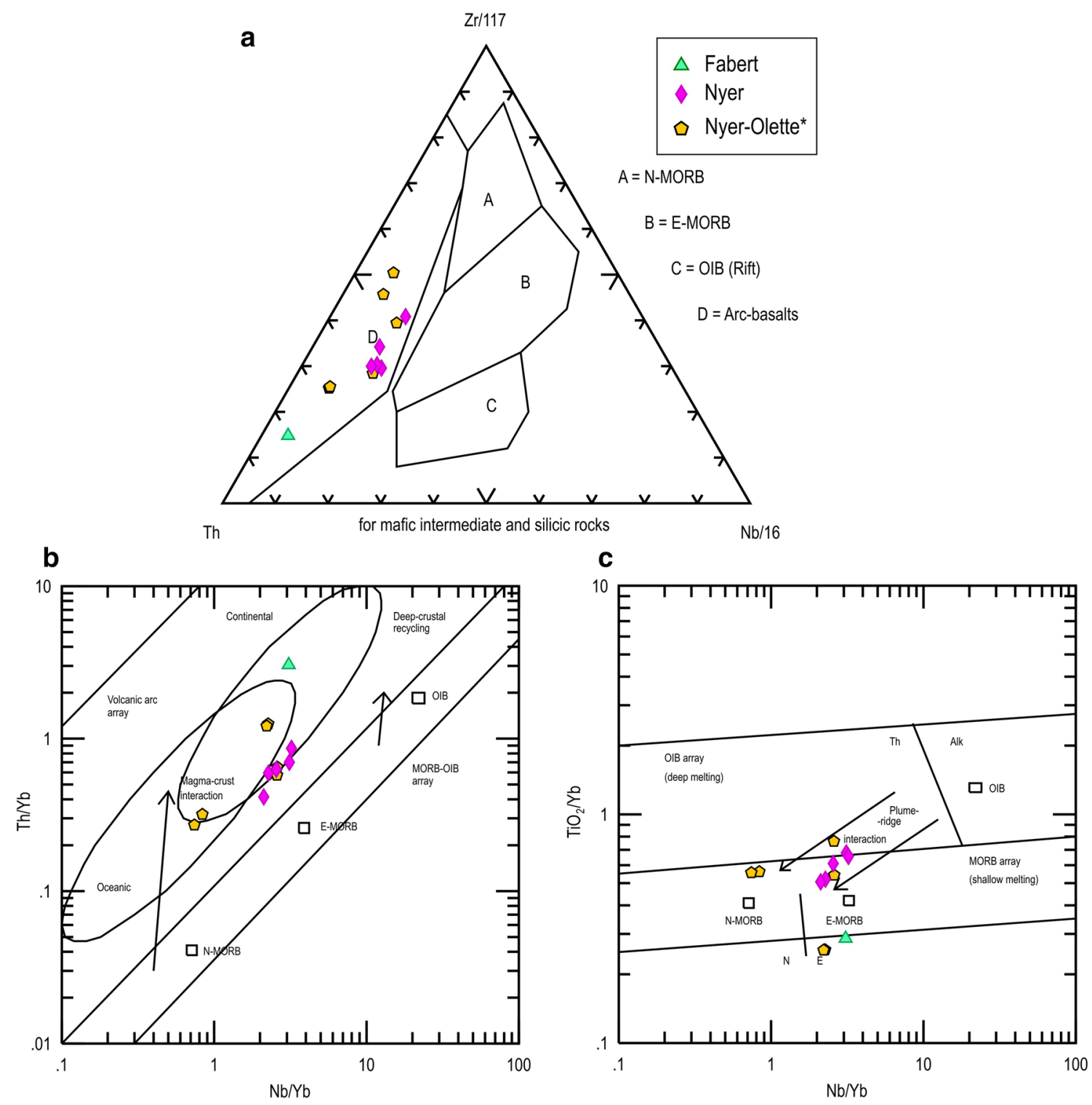

Fig. 8 Tectonic discriminating diagrams a Th-Zr-Nb ternary tectonic diagram of Wood (1980). b Th/Yb vs. Nb/Yb of Pearce (2008). c TiO $/$ Yb vs. $\mathrm{Nb} / \mathrm{Yb}$ of Pearce (2008); legend as Fig. 5

respectively. The Nyer*, Nyer-Olette* and Finestrelles sets present similar values, with $(\mathrm{La} / \mathrm{Sm})_{n}$ average $=2.56,2.68$ and 2.94, respectively. All of them show strong Eu negative anomalies (Fig. 9a, b), indicating plagioclase fractionation. This may be linked to a crustal origin characterised by a negative anomaly, albeit a relationship with mafic magma fractionation cannot be ruled out. The latter interpretation would be supported by its high content in $\mathrm{Zr}$ (> $200 \mathrm{ppm}$ in almost all sets of rocks, except in Nyer-Olette*, where it is $190 \mathrm{ppm})$.

Average values of the nearly all sets (except Nyer-Olette*) show values close to the average Upper Crust of Rudnick and Gao (2004), except for the (La/Y) ${ }_{n}$ and (La/ $\mathrm{Sm})_{n}$ ratios, which are close to those characteristic of the
Lower Continental Crust. The Nyer-Olette* set displays enrichment in the $\mathrm{La} / \mathrm{Nb}$ and $\mathrm{Th} / \mathrm{Nb}$ ratios and depletion in the $\mathrm{Th} / \mathrm{La}$ and $\mathrm{Nb} / \mathrm{Y}$ ones by comparison with the Upper Continental Crust (Fig. 7b; Table 1).

The geochemical characterisation of the tectonic setting (Fig. 9c, d) is not straightforward, as the dataset overlaps both the anorogenic and orogenic fields in the Pearce et al.'s (1984) diagram. The geochemical signature in the $\mathrm{Zr}$ vs. $\mathrm{TiO}_{2}$ diagram is not distinct: most samples plot in the arc association, whereas a sample from the Olette Formation (LPT2) plots in the extensional field. All the geochemical characters outlined above suggest that these rocks were mainly derived from a continental crustal source, although 

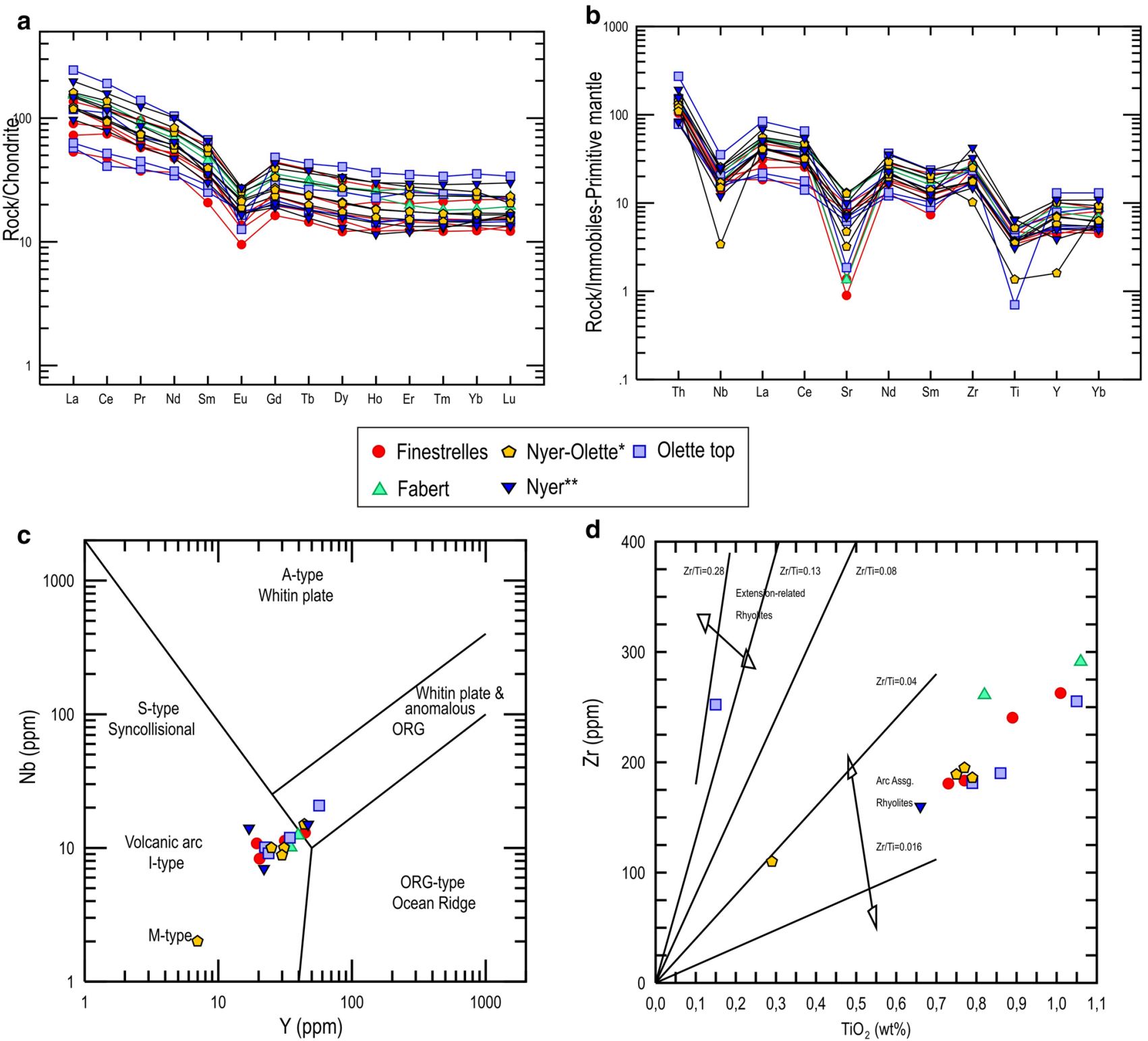

Fig. 9 Geochemical features of the Ediacaran felsic and intermediate rocks from the Canaveilles Group. a Chondrite-normalised REE patterns (normalising values from Sun and McDonough 1989). b Multi-element diagram normalised to Primitive Mantle of Palme and

they display some features that evidence a more important lithospheric influence.

\section{Sm-Nd isotopic data}

The Sm-Nd isotopic system is a good indicator of the original composition of the rocks because their elementary distribution is not significantly affected during sedimentary, diagenetic and/or metamorphic processes (McCulloch and Wasserburg 1978; Arndt and Goldstein 1987), albeit some values (samples PIR100 and PC22) are above the upper limit

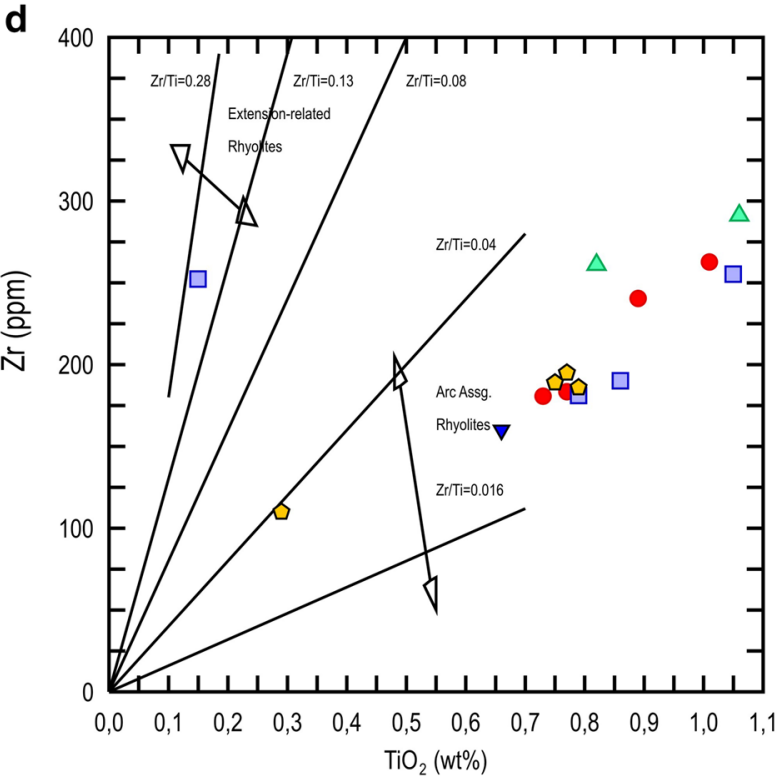

O'Neill (2004) for Ediacaran felsic and intermediate rocks. c Tectonic discriminating diagram $\mathrm{Yb}$ vs. $\mathrm{Nb}$ of Pearce et al. (1984). d Tectonic discriminating diagram ( $\mathrm{Zr}$ vs. $\mathrm{TiO}_{2}$ ) of Syme (1998); legend as Fig. 5

$\left({ }^{147} \mathrm{Sm} /{ }^{144} \mathrm{Nd}=0.15\right)$ proposed by Stern (2002) as suitable to perform $\mathrm{Nd} T_{\mathrm{DM}}$ calculations. The $\mathrm{Sm}-\mathrm{Nd}$ isotopic data obtained from the metabasites are given in Table 1 and plotted in Fig. 10. Ages $(t)$ for the $\varepsilon \mathrm{Nd}_{t}$ were estimated according to stratigraphic and structural features, while the epsilon calculations were done following the formulas of DePaolo and Wasserburg (1976) and DePaolo (1981). It is remarkable the small amount of analyses available and the fact that absolute ages are only available for felsic rocks, the ages of the metabasite protoliths being still unknown. We choose a similar Ediacaran age for the metabasaltic lava flows interbedded in 
Fig. $10 \varepsilon \mathrm{Nd}$ vs. age diagram for the Ediacaran magmatic rocks of the Pyrenees; depleted mantle evolution calculated according to DePaolo (1981); DM Depleted Mantle, CHUR Chondritic Uniform Reservoir; see stratigraphic setting of samples in Fig. 2

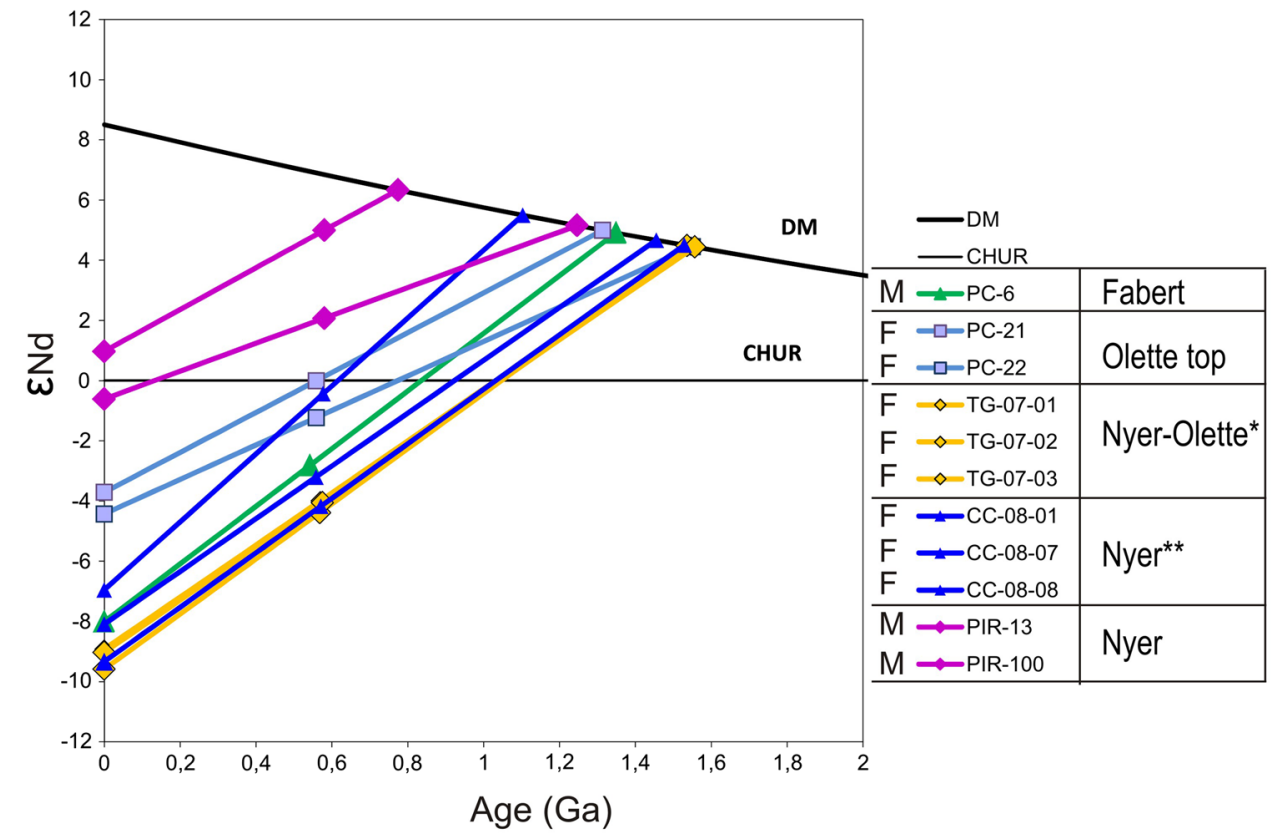

the lower part of the succession, although the protolith age of the plutonic metabasites remains unresolved and a younger pre-Variscan (Ordovician?) age cannot be completely ruled out. Further geochemical and geochronological studies are needed in order to resolve this issue. The reference age used for the emplacement of the basanite embedded in the Fabert Member is $542 \mathrm{Ma}$, and $559 \mathrm{Ma}$ for the basalts of the Nyer Formation. The analysed rocks show ${ }^{147} \mathrm{Sm} /{ }^{144} \mathrm{Nd}$ ratios varying from 0.1605 to 0.1217 . The higher values correspond to the samples from the Nyer Formation and the lower ones to those from the Fabert Member. Samples from the Nyer Formation show positive $\varepsilon \mathrm{Nd}(\mathrm{t})$ values ranging from +5.0 to +2.1 and $\mathrm{T}_{\mathrm{DM}}$ ages from 0.77 to $1.25 \mathrm{Ga}$ (Pir13 and Pir100 samples, respectively). The basaltic andesite embedded in the Fabert Member (PC6) yields a negative value of -2.8 and a $\mathrm{T}_{\mathrm{DM}}$ age of $1.35 \mathrm{Ga}$. Therefore, the Nyer volcanics yields a much more primitive isotopic signature than the Fabert volcanics, with a negative $\varepsilon \mathrm{Nd}(t)$ value indicative of significant crustal contamination at its source.

The Sm-Nd isotopic data obtained from the top of the Olette Formation are given in Table 1 and plotted in Fig. 10. The reference age considered for the emplacement of the rhyolitic pulses is 559 Ma, according to DePaolo's (1981) equation. The analysed rocks show ${ }^{147} \mathrm{Sm} /{ }^{144} \mathrm{Nd}$ ratios varying from 0.1519 to 0.1448 (PC22 and PC21, respectively). They show moderately negative $\varepsilon \mathrm{Nd}$ values ranging from 0.0 to -1.2 and $\mathrm{T}_{\mathrm{DM}}$ ages varying between 1.31 and $1.55 \mathrm{Ga}$. These values suggest crustal contamination at its source.

This isotopic dataset can be compared to the results obtained by Casas et al. (2015) for the felsic metavolcanic rocks from the Nyer** Formation and the Finestrelles Member, with $\varepsilon N d(t)$ values ranging between -0.6 and -4.3 in the
Cap de Creus unit, and -4.0 and -4.6 in the Puigmal unit (Tregurà), with TDM ages ranging from 1.12 to $1.6 \mathrm{Ga}$. This dataset may be interpreted as the result of variable mixing of crustal components as it has already been described in other areas of the European Variscan Belt, such as the Bohemian Massif, where felsic igneous rocks provide $\varepsilon N d$ values between -3.3 and -7.9 ( -3.3 to -5.0 by Linnemann and Romer 2002, and -4.9 to -7.9 by Mingram et al. 2004). These authors interpreted the corresponding Mesoproterozoic (between 1.6 and $1.9 \mathrm{Ga}$ ) TDM ages as the result of the mixing of Palaeoproterozoic-Archean and Neoproterozoic crustal portions.

\section{$\mathrm{U}-\mathrm{Pb}$ zircon dating}

A revision of previously published $\mathrm{U}-\mathrm{Pb}$ zircon ages and a selection of key volcanic levels are documented below in order to reconstruct the geometrical relationships of their volcanosedimentary bodies.

\section{Revision of available radiometric ages}

During the last two decades, the following U-Pb zircon dating studies (LA-ICPMS and SIMS) have been performed in the Canaveilles volcanic and volcanosedimentary deposits preserved in the Puigmal and Cap de Creus units.

- The first U-Pb (SIMS) dating yielded an average age of $580 \pm 10 \mathrm{Ma}(\mathrm{MSWD}=2.2$; sample GRA1, $\mathrm{n}=8 / 19$ ) for some metarhyolitic layers (VS1 sensu Laumonier et al. 2004) interbedded in the Nyer Formation of the Vallespir unit (Cocherie et al. 2005). According to Wendt and Carl 
(1991) and Spencer et al. (2016), the resulting MSWD value of 2.2 is slightly too high (as it should not exceed 2). In addition, this age was calculated after excluding the two youngest (perfectly concordant) zircon analyses, interpreted by the authors as resulting from a slight $\mathrm{Pb}$ loss; and the eight analyses used for the age calculation were either poorly concordant or slightly discordant, thus needing a re-evaluation.

- In the Puigmal unit, one metatuff interlayered in the schists of the Olette Formation was dated using SHRIMP (SIMS) at $548.4 \pm 8.4 \mathrm{Ma}$ (sample RF3, $\mathrm{n}=7 / 11$; Castiñeiras et al. 2008) with a MSWD $=0.73$.

- The Finestrelles Member was previously dated by Casas et al. (2015) on samples collected in the vicinity of the Tregurà village, who interpreted them as ignimbrites. These outcrops have been reinterpreted above as volcaniclastic breccia-dominated aprons made up after reworking of ignimbritic deposits. In addition, the method used by the authors to separate their zircon grains did not follow the recommendation of Slama and Košler (2012), as they deliberately selected the most pristine grains (see p. 915). We propose here to reconsider the zircon distribution of the three samples from the Puigmal unit (TG0701-02-03 of Casas et al. 2015) based on the sedimentary slope-related mixing recorded by the involved ignimbrites. We suggest instead recalculating the age as a maximum (re)depositional age and propose, based on the three youngest, concordant and equivalent dates within error, using the mean weighted average age: $\mathrm{TG} 0701=559 \pm 9, \mathrm{TG} 0702=552 \pm 10$ and $\mathrm{TG} 0703=565 \pm 9 \mathrm{Ma}$.

- In the Cap de Creus unit, some decimetre-thick trachyandesitic meta-ash tuffs are located at the bottom of the Nyer Formation (CC08-01, 577 \pm 3 Ma: Casas et al. 2015), whereas metre-scale metatuffs crop out at the top of the Olette Formation (CC08-08, 558 \pm 3 Ma: Casas et al. 2015)

\section{New U-Pb dating}

Four samples have been dated by LA-ICP-MS during two separate analytical sessions (Fig. 11; Repository Data 2):

- Two metarhyolites from the Fabert Member in the Puigmal unit were sampled to obtain their depositional age: FA1 and PC5.

FA1 was sampled at the stratotype (near the Fabert torrent). One hundred and thirteen analyses have been performed out of which 104 are $\pm 10 \%$ discordant. The density distribution curve (Fig. 12) shows one distinct single peak at ca. $560 \mathrm{Ma}$, whereas the remaining data relate to Proterozoic and Archean inherited dates. Using the 25 youngest concordant dates, we obtain a Concordia date of $558.9 \pm 2.4 \mathrm{Ma}$ $(\mathrm{MSWD}=0.29$ at $2 \sigma$; Fig. 13). The TuffZirc algorithm returns a date of $559.1+1.75 /-1.35 \mathrm{Ma}(N=50 / 104$; Fig. 13), within error with the Concordia date that we consider as the depositional age for this sample. This age is identical within error with the age of $559.9 \pm 9.0 \mathrm{Ma}$ obtained by Laumonier et al. (2015b) on the same metarhyolites.

PC5 was sampled at the Pic de la Clape summit. Forty seven of the 60 analyses are $\pm 10 \%$ discordant. The density distribution curve (Fig. 12) shows one distinct single peak at ca. $542 \mathrm{Ma}$ with scattered Proterozoic inherited dates. Using the 5 youngest concordant dates (Fig. 13), we obtain a concordia date of $542.8 \pm 5.4 \mathrm{Ma}(\mathrm{MSWD}=0.35$ at $2 \sigma)$. The TuffZirc algorithm returns a similar date at $542.9+5.0 /-1.30 \mathrm{Ma}$, using 33 of the 47 dates (33/47; Fig. 13) that we interpret as the depositional age (Fig. 12).

- The volcanosedimentary breccia and tuffaceous sandstone of the Finestrelles Member have been sampled at the Pic de Finestrelles (FIN11) and Pic de la Clape (PC11) summits, in order to compare their respective maximum depositional ages yielded for these samples and those of the same member in the vicinity of Tregurà (Casas et al. 2015).

In the tuffaceous sandstone FIN11, 109 of the 111 analyses were kept for statistical analyses (concordancy between 90-110\%). The density distribution curve (Fig. 12) shows one main peak at ca. $610 \mathrm{Ma}$, with 5 other secondary peaks at ca. $560 \mathrm{Ma}, 785 \mathrm{Ma}, 970 \mathrm{Ma}, 2.5 \mathrm{Ga}, 2.7 \mathrm{Ga}$, the remaining data defining discrete Proterozoic and Archean dates. The three youngest concordant dates, ranging between 554 and $557 \mathrm{Ma}$, yield an average ${ }^{206} \mathrm{~Pb} /{ }^{238} \mathrm{U}$ date of $556.0 \pm 6.9 \mathrm{Ma}$ (MSWD $=0.42$; Fig. 13), which is considered as the maximum depositional age (Fig. 12).

In the breccia sample PC11, 124 of the 140 analyses were kept for statistical analyses (concordancy between 90-110\%). The density distribution curve (Fig. 12) shows one main peak at ca. $537 \mathrm{Ma}$, with six other secondary peaks at ca. $600 \mathrm{Ma}, 710 \mathrm{Ma}, 780 \mathrm{Ma}, 830 \mathrm{Ma}, 910 \mathrm{Ma}, 2.5 \mathrm{Ga}$, the remaining data defining discrete Proterozoic and Archean dates. The four youngest and most concordant dates, ranging between 525 and $539 \mathrm{Ma}$, yield an average ${ }^{206} \mathrm{~Pb} /{ }^{238} \mathrm{U}$ date of $532.9 \pm 6.0 \mathrm{Ma}$ (MSWD $=0.77$; Fig. 13), which is considered as the maximum depositional age (Fig. 12).

\section{Geometry of the volcanosedimentary complexes}

We propose here a new model for the Cadomian volcanosedimentary evolution recorded in the Eastern Pyrenees, based on the sedimentary, geochemical and geochronological data 
Fig. 11 Example of CLimaging for analysed zircon. a Sample FA1. b Sample PC5. c Sample FIN11. d Sample PC11; scale bars $50 \mu \mathrm{m}$; zircon numbers (ZRxx) and ages from supplementary tables

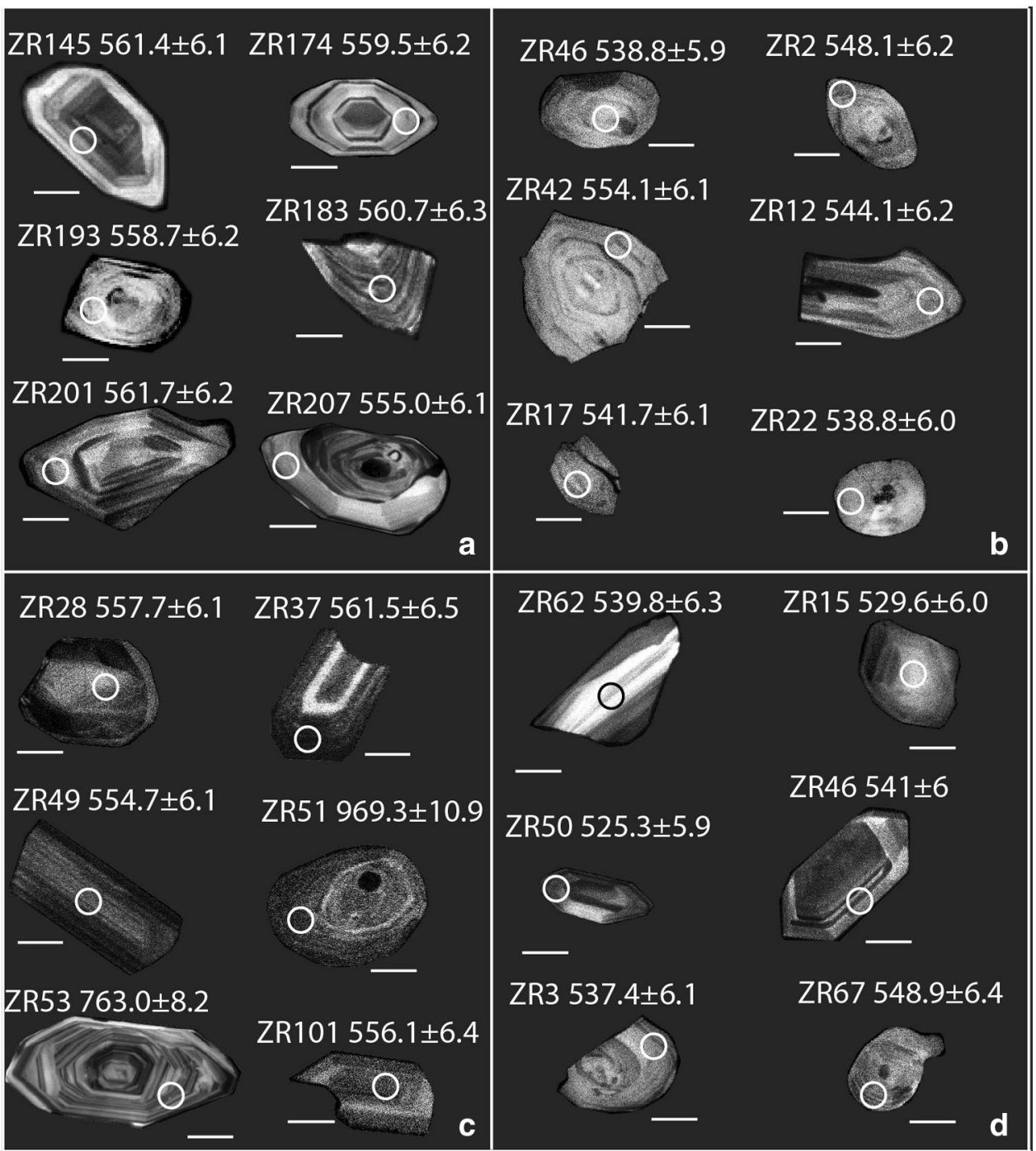

reported above. At a first order, abrupt lithofacies changes and pinch-and-swelling (or lenticular) geometries suggest significant modifications of transport and depositional processes over short distances from vent sources.

Although the Fabert Member was previously interpreted as a single stratigraphic marker bed, two metarhyolite samples from this member have yielded two different ages separated by ca. 17 m.y. $(559.00+1.75 /-1.35$ Ma for the Fabert village, and 542.9+5.0/- 1.3 Ma for the Pic de la Clape summit), thus reflecting two distinct felsic magma emplacements that display similar geochemical composition.

The overlying Finestrelles Member displays complex lateral facies associations, which change from thick, massive or normal graded volcaniclastic breccias (close to vent areas) to thin- and medium-bedded tuffaceous sandstones, displaying plane-parallel and through cross-stratification, toward distal areas and as a result of reworking. Three volcanosedimentary edifices can be recognised based on the abovereported $\mathrm{U}-\mathrm{Pb}$ zircon dating constraints, palaeotopographic relationships linked to onlap geometries and distance from sources (from near-vent to distal areas), the so-called Tregurà (ca. 565-552 Ma), Cap de Creus (ca. $558 \mathrm{Ma}$ ) and Coll d'Ares (ca. 542-532 Ma) edifices (Fig. 2). The Tregurà edifice comprises three disconnected outcrops at the Pic de Finestrelles summit, Tregurà and Fabert villages (Fig. 1b). This cartographic disconnection precludes the assignation of these exposures to a single edifice, as a result of which, we cannot eliminate the possibility of the onset of three separated (but contemporaneous) volcanosedimentary edifices, displaying similar geochemical features, for what we name Tregurà edifice. In contrast, an apparent cartographic continuity is recognised linking the volcanosedimentary outcrops of Fabert village to the Coll d'Ares-Tour de Mir-Pic de la Clape area; however, their respective $\mathrm{U}-\mathrm{Pb}$ zircon dating allows distinction of two diachronous edifices, the latter (Coll d'Ares edifice) geometrically overlapping the former (Fig. 2). 

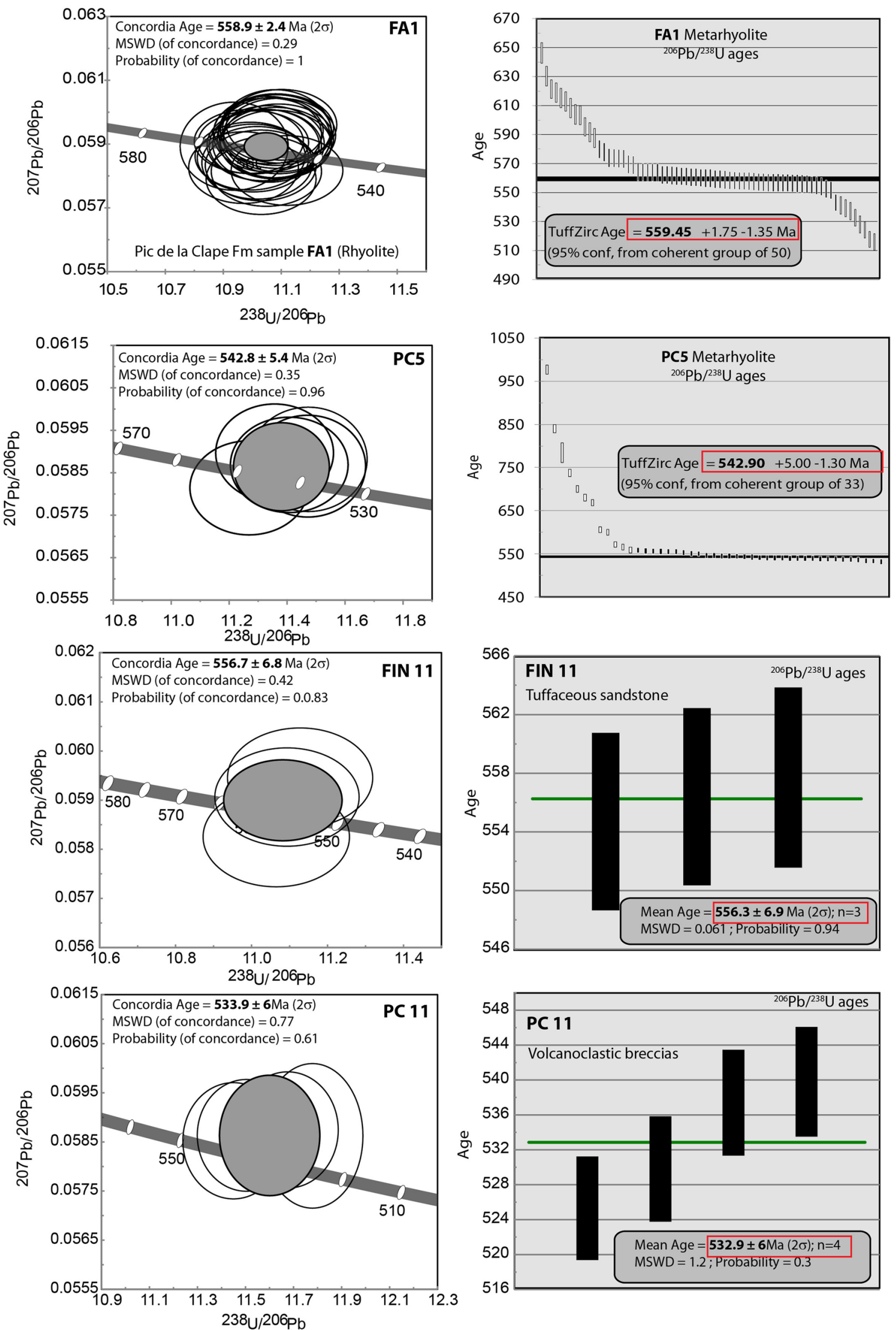

Fig. 12 Age distribution curve and age repartition of zircon grains from the Fabert metarhyolithes (PC5 and FA1) and the Finestrelles volcanoclastic breccia (TG0701, TG0702, TG0703, PC11) and tuffaceous sandstone (FIN11); data from TG after Casas et al. (2015) 
Fig. 13 Tera-Wasserburg Concordia diagrams (left side) and TuffZirc and Weighted Average diagrams (right side) of the analysed samples PC5, FA1, PC11 and FIN11 (see their stratigraphic and geotectonic setting in Fig. 2). The depositional age of the Fabert metarhyolites (PC5, FA1) and the maximum depositional age of the Finestrelles volcanoclastic breccia (PC11) and tuffaceous sandstone (FIN11) are indicated in the red boxes

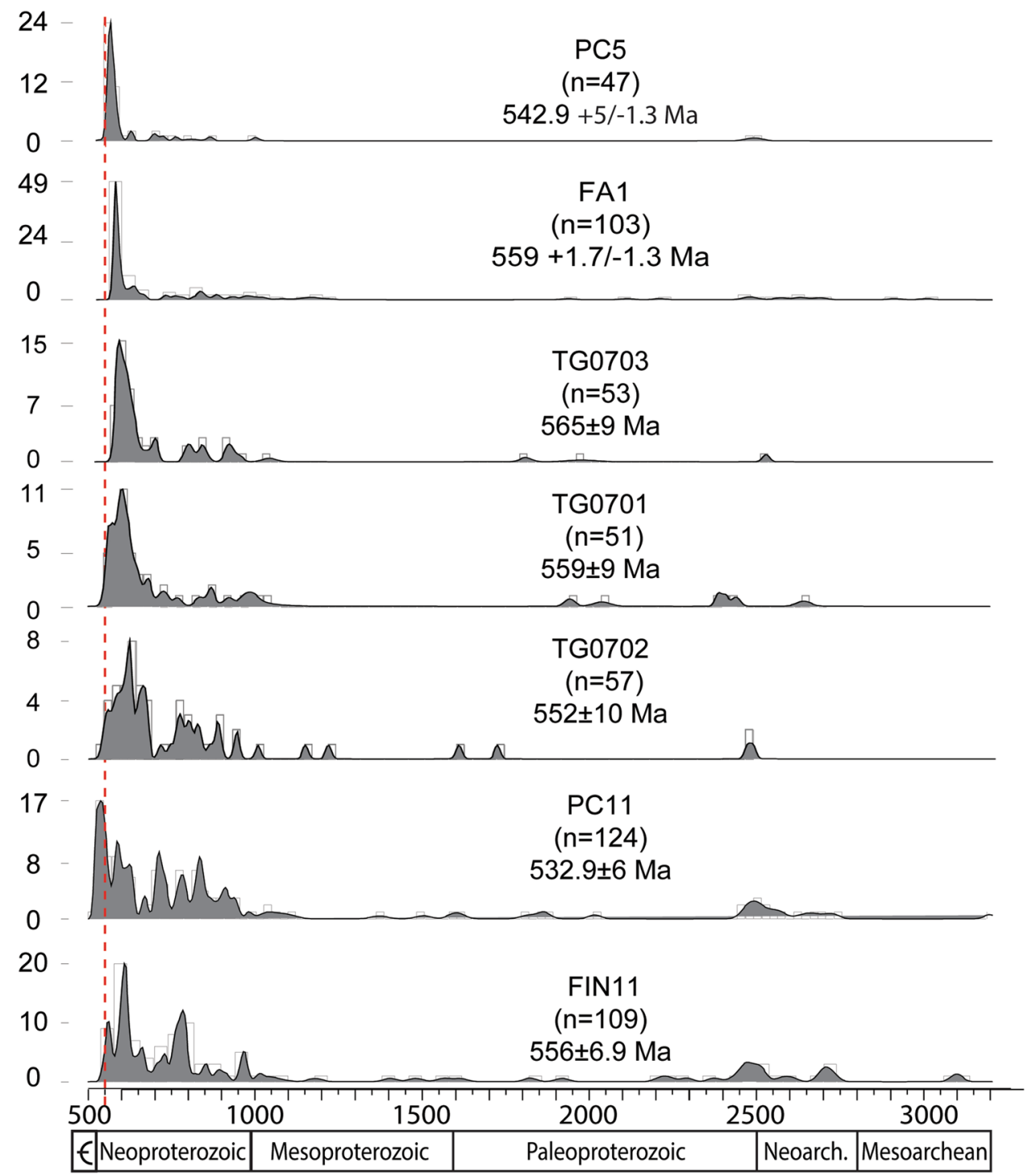

The Tregurà and Coll d'Ares edifices represent explosive felsic eruptions that dispersed their volcanic products over large (km-scale) areas. They display similar petrochemical features but different radiometric ages. The edifices represent pyroclastic-dominated, planoconvex-like bodies, up to $500 \mathrm{~m}$ thick, with gradual topographically controlled northand northwesternward decreasing thicknesses. (Volcani)clastic input precluded carbonate production, so discontinuities punctuating the volcanosedimentary complexes are marked by short-term episodes of carbonate production that points to unconformity-bounded inter-eruptive episodes. These carbonate interbeds mark successive calm volcanic episodes, interrupted by volcanic eruption and remobilisation of the previously deposited volcanosedimentary edifices. The end of the volcanic activity was marked by nucleation and development of fringing centres of carbonate factories. The latter led to microbial carbonate production close to subaerial exposure on the top of some palaeorelief highs.
This episodic record of substrate instability was responsible for the development of tilting and fissuring, and subsequent drowning. The volcanosedimentary complexes were finally sealed by the shales of the Jujols Group.

The volcanic activity recorded in the Pic de la Clape Formation began on a deep ocean with a substrate covered with black sulfidic shales (Olette Formation). After emplacement of the volcanic activity and local development of carbonate production, the volcanic edifices rapidly subsided and were subsequently sealed by the Jujols Group. Contemporaneous tectonic activity (or substrate instability) was exclusively located throughout the above-reported volcanosedimentary edifices and may be explained as episodes of seafloor instability recorded in response to overall differential subsidence determined by the surrounding volcanosedimentary topography. No significant synsedimentary faulting has yet been reported in laterally equivalent strata crossing the Canaveilles/Jujols contact. The shallowing associated with the onset 
of the Pic de la Clape Formation is exclusively restricted to the Puigmal unit and related to the onset of volcanic activity.

\section{Cadomian arc-related events in West Gondwana}

The lava flows and sills hosted by the Nyer and Olette formations point to a tholeiitic magmatism probably linked to Ediacaran extensional conditions and preceding the record of Cadomian magmatism. Similar pre-Cadomian, riftrelated magmatic products are recorded in the Ediacaran Serie Negra Group of Ossa-Morena (590-545 Ma), which displays oceanic environments with island-arc affinity linked to fore- and back-arc basins (Ribeiro et al. 2003; Sánchez Lorda et al. 2013).

Comparable volcanic activities to those recorded at the top of the Olette Formation and within the Fabert and Finestrelles members are represented by the Ouarzazate Supergroup of the Anti-Atlas in Morocco (ca. 615-548 Ma; Gasquet et al. 2005; Pouclet et al. 2007; Walsh et al. 2012; Álvaro et al. 2014a), the Malcocinado Group of the OssaMorena Zone in SW Iberia (587-540 Ma; Sánchez-García et al. 2003, 2010), some reworked clasts lining the Narcea/ Herrería contact in the Cantabrian Zone (ca. 575-560 Ma; Rubio-Ordóñez et al. 2015), and the Sériès Tuffs of the Axial Zone and the Rivernous Formation of the northern Montagne Noire in the Occitan Domain (ca. 542-539 Ma; Lescuyer and Cocherie 1992; Laumonier et al. 2004; Álvaro et al. 2014b; Pouclet et al. 2017; Padel et al. in press). Some detrital zircon grains sampled in the Sand Vito and Gennargentu phyllites from the nappe zone of Sardinia have recently yielded an age bracket between 576 and 539 Ma, which should be representative of a Cadomian magmatic influence (Meloni 2016; Oggiano, pers. commun.).

All these felsic activities are attributed to the arc-related final stage of the Pan-African (in the Anti-Atlas) to Cadomian (in SW Europe) orogens. The diachronous character of the above-reported ages reflects an SW-NE trending of active subduction migrating from the Moroccan to the OssaMorena and Armorican, outer margins of West Gondwana. Despite the lack of associated deformation, the inner periGondwanan margins recorded a parallel SW-NE trending of calc-alkaline, felsic volcanism that finally reached the Pyrenean and Occitan Domains and Sardinia. Mafic volcanism is not yet recognised in the Cambrian-Lower Ordovician of the Eastern Pyrenees, as a result of which, no volcanic products are representative of the Cambrian (post-Terreneuvian) rifting conditions that characterise the neighbouring Montagne Noire (Álvaro et al. 2014a; Pouclet et al. 2017, and references therein).

Although the northeastern (palaeogeographic) prolongation of Sardinia during the Cambrian is still a matter of discussion, the Alpine Briançonnais Domain (Stampfli 1993) offers many magmatic similarities with the abovereported SW-NE geodynamic trend recorded along West Gondwana. A distinct arc/rift change of its magmatic evolution is marked from 550-530 Ma volcanic arc basalts to 530-520 eclogitised gabbroic and tonalitic melts intruding a continental margin magmatic arc (Von Raumer and Stampfli 2008; Von Raumer et al. 2015).

Throughout West Gondwana, the development of carbonate production across the Ediacaran-Cambrian transition is exclusively recorded in margins far from subduction trenches, such as those recorded in the Central-Iberian Zone (Cloudina-bearing mounds; Cortijo et al. 2010), the northern Montagne Noire (Terreneuvian shelly phosphate-rich limestones of the Heraultia Member; Devaere et al. 2013; Álvaro et al. 2014b) and the lateral equivalent, peritidal-dominated, Puig Sec Member of the Eastern Pyrenees (this work).

\section{Conclusions}

The volcanism hosted by the Ediacaran Canaveilles Group of the Eastern Pyrenees displays two distinct geochemical affinities: (1) metabasites of the Nyer and Olette formations reflect the emplacement of tholeiitic volcanic events linked to Ediacaran regional extension, whereas (2) the overlying calc-alkaline, felsic volcanics at the top of the Olette Formation and in the Fabert and Finestrelles members (Pic de la Clape Formation) represent Cadomian magmatic events.

Compared with similar volcanic features from the AntiAtlas, the Iberian Massif and the Montagne Noire, a distinct SW-NE diachronic evolutionary trend can be outlined. PanAfrican/Cadomian deformation is recorded in outer periGondwanan margins (e.g. Anti-Atlas, Ossa-Morena, Cantabrian and West Asturian-Leonese Zones, and North- and Central-Armorican Domains), whereas it is absent in backarc settings (Central Iberian Zone) and inner margins of the eastern Ibero-Armorican Arc (Montagne Noire and Pyrenees). Despite the absence of deformation, the latter inner margins have recorded a parallel SW-NE trending Cadomian calc-alkaline felsic volcanic evolution, the most representative being recognised in the Fabert and Finestrelles members of the Puigmal and Cap de Creus units from the Eastern Pyrenees. Based on $\mathrm{U}-\mathrm{Pb}$ zircon dating, palaeotopography, onlapping geometries and distance from the sources, three volcanosedimentary edifices can be identified, named, from near-vent to distal areas, Tregurà (ca. 565-552 Ma), Cap de Creus (ca. $542 \mathrm{Ma}$ ) and Coll d'Ares (ca. 542-532 Ma) edifices. The top of the palaeoreliefs formed by the volcanosedimentary edifices recorded the local nucleation and lateral migration of centres of carbonate production (Puig Sec Member), characterised by microbial carbonate productivity on peritidal environments linked to synsedimentary tilting, 
fissuring and karstification. The presence of carbonate production across the Ediacaran-Cambrian transition is exclusively located in areas far from the Cadomian subduction suture and devoid of significant terrigenous input, such as those reported in the Eastern Pyrenees and Montagne Noire.

Acknowledgements The authors are indebted to Bernard Laumonier by his invaluable discussions in the field, and to Profs. Jürgen von Raumer and Holger Paulick by their useful and constructive revisions. Funding for this research was yielded by RGF program of the French Geological Survey (BRGM) and projects CGL2013-48877-P and CGL2015-66335-C2-1-R from Spanish MINECO.

\section{References}

Álvaro JJ, Benziane F, Thomas R, Walsh GJ, Yazidi A (2014a) Neoproterozoic-Cambrian stratigraphic framework of the Anti-Atlas and Ouzellagh promontory (High Atlas), Morocco. J Afr Earth Sci 98:1-15

Álvaro JJ, Bauluz B, Clausen S, Devaere L, Gil Imaz A, Monceret E, Vizcaïno D (2014b) Stratigraphic review of the Cambrian-Lower Ordovician volcanosedimentary complexes from the northern Montagne Noire, France. Stratigraphy 11:83-96

Álvaro JJ, Casas JM, Clausen S, Padel M, Sánchez-García T (in press) Cadomian cycle in the Pyrenees. In: Quesada C, Oliveira JT (eds) The geology of Iberia: a geodynamic approach. Regional Geology Reviews series. Springer, Heidelberg

Arndt NT, Goldstein SL (1987) Use and abuse of crust formation ages. Geology 15:893-895

Ayora C, Casas JM (1986) Stratabound As-Au mineralization in preCaradocian rocks from the Vall de Ribes, Eastern Pyrenees, Spain. Mineralium Deposita 21:278-287

Ballèvre M, Le Goff E, Hébert R (2001) The tectonothermal evolution of the Cadomian belt of northern Brittany, France: a Neoproterozoic volcanic arc. Tectonophysics 331:19-43

Bandrés A, Eguíluz L, Gil Ibarguchi JI, Palacios T (2002) Geodynamic evolution of a Cadomian arc region: the northern Ossa-Morena Zone, Iberian massif. Tectonophysics 352:105-120

Baudin T, Autran A, Guitard G, Laumonier B (2008) Carte géologique de France (1/50 000). Feuille Arles-Sur-Tech (1100). BRGM, Orléans

Bowring SA, Schoene B, Crowley JL, Ramezani J, Condon DJ (2006) High-precision $\mathrm{U}-\mathrm{Pb}$ zircon geochronology and the stratigraphic record: progress and promise. Geochronology: emerging opportunities, paleontological society short course. Paleontol Soc Pap 11:23-43

Bull KF, McPhie J (2007) Fiamme textures in volcanic successions: flaming issues of deformation and interpretation. J Volcanol Geotherm Res 164:205-216

Casas JM, Martí J, Ayora C (1986) Importance du volcanisme dans la composition lithostratigraphique du Paléozoïque inférieur des Pyrénées Catalanes. C R Acad Sci, Paris (sér 2) 302(19):1193-1198

Casas JM, Castiñeiras P, Navidad M, Liesa M, Carreras J (2010) New insights into the Late Ordovician magmatism in the Eastern Pyrenees: U-Pb SHRIMP zircon data from the Canigó massif. Gondwana Res 17:317-324

Casas JM, Navidad M, Castiñeiras P, Liesa M, Aguilar C, Carreras J, Hofmann M, Gärtner A, Linnemann U (2015) The Late Neoproterozoic magmatism in the Ediacaran series of the Eastern Pyrenees: new ages and isotope geochemistry. Int J Earth Sci 104:909-925
Castiñeiras P, Navidad M, Liesa M, Carreras J, Casas JM (2008) U-Pb zircon ages (SHRIMP) for Cadomian and Lower Ordovician magmatism in the Eastern Pyrenees: new insights in the pre-Variscan evolution of the northern Gondwana margin. Tectonophysics 461:228-239

Cavet P (1957) Le Paléozoïque de la zone axiale des Pyrénées orientales françaises entre le Roussillon et l'Andorre. Bull Sér Carte géol Fr 55:303-518

Cirés J, Casas JM, Muñoz JA, Fleta J, Barbera M (1995) Memoria explicativa del mapa geológico de España a escala 1:50.000. Hoja de Molló (n²18). ITGE, Madrid

Cocherie A, Baudin T, Autran A, Guerrot C, Fanning M, Laumonier $\mathrm{B}$ (2005) U-Pb zircon (ID-TIMS and SHRIMP) evidence for the early Ordovician intrusion of metagranites in the late Proterozoic Canaveilles Group of the Pyrenees and the Montagne Noire (France). Bull Soc géol Fr 176:269-282

Cortijo I, Martí Mus M, Jensen S, Palacios T (2010) A new species of Cloudina from the terminal Ediacaran of Spain. Precambr Res 176:1-10

Deloule E, Alexandrov P, Cheilletz A, Laumonier B, Barbey P (2002) In situ $\mathrm{U}-\mathrm{Pb}$ zircon ages for Early Ordovician magmatism in the eastern Pyrenees, France: the Canigou orthogneisses. Int J Earth Sci 91:398-405

Denele Y, Barbey P, Deloule E, Pelleter E, Olivier P, Gleizes G (2009) Middle Ordovician U-Pb age of the Aston and Hospitalet orthogneissic laccoliths: their role in the Variscan evolution of the Pyrenees. Bull Soc géol Fr 180:209-221

DePaolo DJ (1981) Neodymiun isotopes in the Colorado Front range and crust-mantle evolution in the Proterozoic. Nature 291:193-196

DePaolo DJ, Wasserburg GJ (1976) Nd isotopic variations and petrogenetic models. Geophys Res Lett 3(5):249-252

Devaere L, Clausen S, Steiner M, Álvaro JJ, Vachard D (2013) Chronostratigraphic and palaeogeographic significance of an early Cambrian microfauna from the Heraultia Limestone, northern Montagne Noire, France. Palaeont Electr 16.2 17A:755-768

Dickinson WR, Gehrels GE (2009) Use of U-Pb ages of detrital zircons to infer maximum depositional ages of strata: a test against a Colorado Plateau Mesozoic database. Earth Planet Sci Lett 288:115-125

Donzeau M, Laumonier B, Guitard G, Autran A, Llac F, Baudin T, Calvet M (2010) Carte géologique de France (1/50 000). Feuille Céret (1096). BRGM, Orléans

Gasquet D, Levresse G, Cheilletz A, Azizi-Samir MR, Mouttaqi A (2005) Contribution to a geodynamic reconstruction of the AntiAtlas (Morocco) during Pan-African times with the emphasis on inversion tectonics and metallogenic activity in the PrecambrianCambrian transition. Precambr Res 140:157-182

Guitard G (1970) Le métamorphisme hercynien mésozonal et les gneiss œillés du massif du Canigou (Pyrénées orientales). Mém BRGM 63:1-353

Guitard G, Laffite P (1956) Sur l'importance et la nature des manifestations volcaniques dans le Paléozoïque inférieur des Pyrénées orientales. C R Acad Sci Paris 242:2749-2752

Guitard G, Laumonier B, Autran A, Bandet Y, Berger GM (1998) Notice explicative, Carte géologique de la France (1/50 000), feuille Prades (1095). BRGM, Orléans, p 198

Irvine I, Baragar WR (1971) A guide to the chemical classification of the common volcanic rocks. Can J Earth Sci 8:523-548

Keppie JD, Nance RD, Murphy JB, Dostal J (2003) Tethyan, Mediterranean, and Pacific analogues for the Neoproterozoic-Paleozoic birth and development of peri-Gondwanan terranes and their transfer to Laurentia and Laurussia. Tectonophysics 365:195-219

Kroner A, Stern RJ (2004) Pan-African orogeny. Encycl Geol 1:1-12 Laumonier B, Abad A, Alonso JL, Baudelot S, Bessière G, Besson $\mathrm{M}$, Bouquet $\mathrm{C}$, Bourrouilh R, Brula $\mathrm{P}$, Carreras J, Centène A, 
Courjault-Radé R, Courtessole R, Fauconnier D, García-Sansegundo J, Guitard G, Moreno-Eiris E, Perejón A, Vizcaïno D (1996) Cambro-Ordovicien. In: Barnolas A, Chiron JC (eds) Synthèse géologique et géophysique des Pyrénées. Tome 1: Cycle Hercynien. BRGM-ITGE, Orléans-Madrid, p 729

Laumonier B, Autran A, Barbey P, Cheilletz A, Baudin T, Cocherie A, Guerrot C (2004) Conséquences de l'absence de socle cadomien sur l'âge et la signification des séries pré-varisques (antéOrdovicien supérieur) du sud de la France (Pyrénées, Montagne Noire). Bull Soc géol Fr 175:105-117

Laumonier B, Calvet M, Wiazemsky M, Barbey P, Marignac C, Lambert J, Lenoble JL (2015a) Notice explicative de la Carte géologique de la France (1/50 000). Feuille Céret (1096). BRGM, Orléans

Laumonier B, Le Bayon B, Calvet M (2015b) Notice explicative de la Carte géologique de France (1/50 000). Feuille Prats-de-Mollo (1099). BRGM, Orléans

Laumonier B, Calvet M, Barbey P, Guennoc P, Lambert J, Lenoble JL, Wiazemsky M (2015c) Notice explicative la Carte géologique de la France (1/50 000). Feuille Argelès-sur-Mer-Cerbère (1097). BRGM, Orléans

Lescuyer JL, Cocherie A (1992) Datation sur monozircons des métadacites de Sériès. Arguments pour un âge protérozoïque terminal des "schistes X" de la Montagne Noire (Massif central français). C R Acad Sci, Paris (sér 2) 314:1071-1077

Liesa M, Carreras J, Castiñeiras P, Casas JM, Navidad M, Vila M (2011) U-Pb zircon of Ordovician magmatism in the Albera Massif (Eastern Pyrenees). Geol Acta 9:93-101

Linnemann U, Romer RL (2002) The Cadomian Orogeny in SaxoThuringia, Germany: geochemical and $\mathrm{Nd}-\mathrm{Sr}-\mathrm{Pb}$ isotopic characterization of marginal basins with constraints to geotectonic setting and provenance. Tectonophysics 352:33-64

Linnemann U, Gerdes A, Drost K, Buschmann B (2007) The continuum between Cadomian Orogenesis and opening of the Rheic Ocean: constraints from LA-ICP-MS U-Pb zircon dating and analysis of plate-tectonic setting (Saxo-Thuringian Zone, NE Bohemian massif, Germany). In: Linnemann U, Nance D, Kraft P, Zulauf G (eds), The Evolution of the Rheic Ocean: from Avalonian-Cadomian active margin to Alleghenian-Variscan collision. Geol Soc Am Bull 423:61-96

Linnemann U, Pereira F, Jeffries TE, Drost K, Gerdes A (2008) The Cadomian Orogeny and the opening of the Rheic Ocean: the diacrony of geotectonic processes constrained by LA-ICP-MS U-Pb zircon dating (Ossa-Morena and Saxo-Thuringian Zones, Iberian and Bohemian Massifs). Tectonophysics 461:21-43

Linnemann U, Gerdes A, Hofmann M, Marko L (2014) The Cadomian Orogen: Neoproterozoic to Early Cambrian crustal growth and orogenic zoning along the periphery of the West African CratonConstraints from $\mathrm{U}-\mathrm{Pb}$ zircon ages and $\mathrm{Hf}$ isotopes (Schwarzburg Antiform, Germany). Precambr Res 244:236-278

Ludwig KR (2012) Users Manual for Isoplot/Ex rev. 3.75. Berkeley Geochronology Center. Spec Publ 5:1-75

Ludwig KR, Mundil R (2002) Extracting reliable U-Pb ages and errors from complex populations of zircons from Phanerozoic tuffs. Geochim Cosmochim Acta 66:A463

Manzotti P, Poujol M, Ballèvre M (2015) Detrital zircon in blueschist-facies meta-conglomerates: implications for the Early Permian palaeo-topography of the Western Alps. Int J Earth Sci 104:703-731

Martínez FJ, Iriondo A, Dietsch C, Aleinikoff JN, Peucat JJ, Cirès J, Reche J, Capdevila R (2011) U-Pb SHRIMP-RG zircon ages and $\mathrm{Nd}$ signature of Lower Paleozoic rifting-related magmatism in the Variscan basement of the Eastern Pyrenees. Lithos 127:10-23

McCulloch MT, Wasserburg GJ (1978) Sm-Nd and Rb-Sr chronology of continental crust formation. Science 200:1003-1011
Meloni M (2016) Tectonic Units of Central Sardinia: structural Evolution and Related Ores. PhD, Sassari University, Italy

Mezger J, Gerdes A (2016) Early Variscan (Visean) granites in the core of central Pyrenean gneiss domes: implications from laser ablation U-Pb and Th-Pb studies. Gondwana Res 29:181-198

Mingram B, Kröner A, Hegner E, Krentz O (2004) Zircon ages, geochemistry, and $\mathrm{Nd}$ isotopic systematics of pre-Variscan orthogneisses from the Erzgebirge, Saxony (Germany), and geodynamic interpretation. Int J Earth Sci (Geol Rundsch) 93:706-727

Murphy JB, Keppie JD, Dostal J, Nance RD (1999) Neoproterozoicearly Paleozoic evolution of Avalonia. In: Laurentia-Gondwana Connections before Pangea. (Ramos VA, Duncan KJ (eds)). Geol Soc Am Spec Pap 336:253-266

Murphy JB, Pisarvesky SA, Nance RD, Keppie JD (2004) Neoproterozoic-Early Paleozoic evolution of peri-Gondwana terranes: implications for Laurentia-Gondwana connections. Int J Earth Sci 93:659-682

Nance DR, Murphy JB, Keppie JD (2002) A Cordilleran model for the evolution of Avalonia. Tectonophysics 352:11-31

Navidad M, Carreras J (2002) El volcanismo de la base del Paleozoico Inferior del Canigó (Pirineos Orientales). Evidencias geoquímicas de la apertura de una cuenca continental. Geogaceta 32:91-94

Navidad M, Liesa M, Carreras J (1996) Magmatismo del Roc de Frausa (Pirineos Orientales). Acta Geol Hisp 31(4):1-15

Padel M, Álvaro JJ, Clausen S, Guillot F, Poujol M, Chichorro M, Monceret E, Pereira MF, Vizcaïno D (in press) U-Pb laser ablation ICP-MS zircon dating across the Ediacaran-Cambrian transition of the Montagne Noire, southern France. C R Geosci. https:// doi.org/10.1016/j.crte.2016.11.002

Palme H, O'Neill HSC (2004) Cosmochemical estimates of mantle composition. In: Carlson RW, Turekian KK (eds) The mantle and core. Treatise on Geochemistry. HD Holland. Elsevier-Pergamon, Oxford, vol 2:pp 1-38

Pearce JA (1996) Sources and setting of granitic rocks. Episodes 19(4):120-125

Pearce JA (2008) Geochemical fingerprinting of oceanic basalts with applications to ophiolite classification and the search for Archean oceanic crust. Lithos 100:14-48

Pearce JA, Harris NBW, Tindle AG (1984) Trace element discrimination diagrams for the tectonic interpretation of granitic rocks. J Petrol 25:956-983

Pereira MF, Chichorro M, Solá AR, Silva JB, Sánchez-García T, Bellido F (2011) Tracing the Cadomian magmatism with detrital/ inherited zircon ages by in-situ U-Pb SHRIMP geochronology (Ossa-Morena Zone, SW Iberian Massif). Lithos 123:204-217

Pouclet A, Aarab A, Fekkak A, Benharref M (2007) Geodynamic evolution of the northwestern Paleo-Gondwana margin in the Moroccan Atlas at the Precambrian-Cambrian boundary. In: Linnemann U, Nance RD, Kraft P, Zulauf G (eds) The Evolution of the Rheic Ocean: from Avalonian-Cadomian Active Margin to Alleghenian-Variscan Collision. Geol Soc Am Spec Pap 423:27-60

Pouclet A, Álvaro JJ, Bardintzeff JM, Gil Imaz A, Monceret E, Vizcaïno D (2017). Cambrian-Early Ordovician volcanism across the South Armorican and Occitan Domains of the Variscan Belt in France: continental break-up and rifting of the northern Gondwana margin. Geosci Frontiers 8:25-64

Reyes J, Villaseca C, Barbero L, Quejido AJ, Santos JF (1997) Descripción de un método de separación de Rb, Sr, Sm y Nd en rocas silicatadas para estudios isotópicos. In: Actas del I Congreso Ibérico de Geoquímica. CEDEX, Soria, pp 46-55

Ribeiro ML, Pereira MF, Solá AR (2003) O ciclo Cadomiano na ZOM: evidencias geoquímicas. Congr Iber Geoqu, Univ Coimbra, Portugal, pp 102-104

Rubio-Ordóñez A, Gutiérrez-Alonso G, Valverde-Vaquero P, CuestaFernández A, Gallastegui G, Gerdes A, Cárdenes V (2015) Arc-related Ediacaran magmatism along the northern margin of 
Gondwana: geochronology and isotopic geochemistry from northern Iberia. Gondwana Res 27:216-227

Rudnick RL, Gao S (2004) Composition of the Continental Crust. In: Holland HD, Turekian KK (eds) The Crust. Treatise on Geochemistry, vol 3. Elsevier-Pergamon, Oxford, pp 1-64

Sánchez Lorda ME, Sarrionandia F, Abalos B, Carracedo M, Eguíluz L, Gil Ibarguchi JL (2013) Geochemistry and paleotectonic setting of Ediacaran metabasites from the Ossa-Morena Zone (SW Iberia). Int J Earth Sci. https://doi.org/10.1007/s00531-013-0937-X

Sánchez-García T, Bellido F, Quesada C (2003) Geodynamic setting and geochemical signatures of Cambrian-Ordovician rift-related igneous rocks (Ossa-Morena zone, SW Iberia). Tectonophysics 365:233-255

Sánchez-García T, Bellido F, Pereira MF, Chichorro M, Quesada C, Pin C, Silva JB (2010) Rift-related volcanism predating the birth of the Rheic Ocean (Ossa-Morena zone, SW Iberia). Gondwana Res 17:392-407

Sláma J, Košler J (2012) Effects of sampling and mineral separation on accuracy of detrital zircon studies. Geochem Geophys Geosyst 13:1-17

Spencer CJ, Kirkland CL, Taylor RJM (2016) Strategies towards statistically robust interpretations of in situ $\mathrm{U}-\mathrm{Pb}$ zircon geochronology. Geosci Frontiers 7:581-589

Stampfli GM (1993) Le Briançonnais, terrain exotique dans les Alpes? Eclog geol Helvetiae 86:1-45

Stern RJ (2002) Crustal evolution in the East African Orogen: a neodymium isotopic perspective. J Afr Earth Sci 34:109-117

Sun SS, McDonough WF (1989) Chemical and isotopic systematics of oceanic basalts; implications for mantle composition and processes. In: Saunders AD, Norry MJ (eds) Magmatism in the Ocean Basins, vol 42. Geol Soc, London, pp 429-448

Syme EC (1998) Ore-associated and barren rhyolites in the central Flin Flon Belt: case study of the Flin Flon mine sequence. Manitoba Energy Mines Open File Rep OF98-9:1-32

Tanaka T, Togashi S, Kamioka H, Dragusanu LC (2000) JNdi-1: a neodymium isotopic reference in consistency with LaJolla neodymium. Chem Geol 168:279-281

Vermeesch P (2004) How many grains are needed for a provenance study? Earth Planet Sci Lett 224:351-441

Von Raumer J, Stampfli GM (2008) The birth of the Rheic Ocean Early Palaeozoic subsidence patterns and tectonic plate scenarios. Tectonophysics 461:9-20

Von Raumer JF, Stampfli GM, Arenas R, Sánchez Martínez S (2015) Ediacaran to Cambrian oceanic rocks of the Gondwana margin and their tectonic interpretation. Int J Earth Sci 104:1107-1121

Walsh GJ, Benziane F, Aleinikoff JN, Harrison RW, Yazidi A, Burton WC, Quick JE, Saadane A (2012) Neoproterozoic tectonic evolution of the Jebel Saghro and Bou Azzer-El Graara inliers, eastern and central Anti-Atlas, Morocco. Precambr Res 216-219:23-62

Wendt I, Carl C (1991) The statistical distribution of the mean squared weighted deviation. Chem Geol Isotope Geosci Sect 86:275-285

Wood DA (1980) The application of a Th-Hf-Ta diagram to problems of tectonomagmatic classification and to establishing the nature of crustal contamination of basaltic lavas of the British Tertiary volcanic province. Earth Planet Sci Lett 50:11-30 